\title{
Rheumatism in industry: a review
}

\author{
J. A. D. ANDERSON \\ Department of Community Medicine, Guy's Hospital Medical School, London SE1
}

\begin{abstract}
Anderson, J. A. D. (1971). Brit. J. industr. Med., 28, 103-121. Rheumatism in industry: a review. Information about causes, effects, and prevention of rheumatic disease among industrial workers lacks standardization, as shown by the literature in this field; one reason for this is that there are discrepancies about the range of diseases and syndromes which should be included under this heading. The Industrial Survey Unit of the Arthritis and Rheumatism Council defined a rheumatic complaint as musculo-skeletal pain not related to recent (i.e., within six weeks) trauma. A study by the Unit of the social and economic effects of rheumatism among 2684 male employees from a range of manual occupations is considered in relation to the observations made by other investigators. Sickness absence (at present estimated to be about 29.8 million working days per annum in Britain) and premature retirement can be shown to result directly from rheumatic complaints, especially rheumatoid arthritis and disc disease; furthermore, there seems to be general agreement that sickness absence is more marked in heavy manual occupations than in light ones. However, the extent to which job changes ascribed to rheumatic complaints are in fact caused by them is more doubtful. Evidence supporting the view that occupational factors are related to the aetiology of some chronic rheumatic diseases is fairly strong. Chronic tenosynovitis, bursitis, osteoarthrosis, and, to a lesser extent, disc disease are among those in which such a relationship can be demonstrated; however, the reason why some men are more prone to develop these conditions than others working in similar jobs is still in doubt, suggesting that the aetiology is multifactorial. In other rheumatic diseases, notably rheumatoid arthritis, a fairly extensive study of the literature does not indicate any clear correlation between occupation and aetiology. A system of job analysis for individual workers based on effort, posture, and climatic conditions at work is suggested. Its use as an alternative to grouping employees under their occupational titles might help to clarify these points. Prevention of rheumatic disease (including the use of pre-employment medical examinations) seems impracticable at the present time, but some progress in tackling the problems of rheumatism among industrial workers might be possible by improving rehabilitative services. These improvements would depend on closer collaboration not only between government departments but among doctors themselves and between them and others working in this field.
\end{abstract}

The control of the spread of infections and increased life expectancy have focused attention on noncommunicable diseases and aroused interest in diseases associated with advancing age. Rheumatic diseases are among those which are becoming increasingly prominent, and recently Jefferys, Millard, Hyman and Warren (1969) found that $3.4 \%$ of adults had motor impairment though not all were suffering from rheumatism.
Concurrently, industry has been concentrated into large units where the productivity of one worker can be compared directly with that of his fellows and these changes have accentuated the importance of disabilities which reduce work speeds. Sickness costs nowadays cannot be measured solely in terms of compensation payments. According to Stern (1946), they must include the cost of losses from reorganization of staff, reduced produc- 
tivity from a team deprived of one member, and falling production of one part leading to falling production of the whole. These views have recently been rephrased by Bell (1969) with particular reference to skilled workers in limited supply in what Abel Smith (1968) has called 'low income countries'.

Another change has been the introduction of social insurance, both nationally and privately. Both sickness absence and premature retirement result in claims and so detailed records have been kept for a number of years. Kahlmeter (1923) observed in Sweden that $9 \%$ of those who had retired prematurely suffered from articular rheumatism. He reported subsequently (Kahlmeter, 1936) that the o rerall rate had increased to $12 \%$, suggesting that these diseases were increasing in importance. He also observed that the prevalence rates for rheumatism were higher in some occupations than in others.

In Britain the Ministry of Health (1924) reported that rheumatic diseases accounted for $15 \%$ of industrial disability in England and Wales and an annual loss of 3.14 million working weeks. Later the Department of Health for Scotland (1945), found that rheumatic diseases accounted for 3.0 million days of incapacity annually. The Scottish report showed a relatively high incidence in the towns and industrial areas.

Duthie and Anderson (1962), collating data from the Ministry of Pensions and National Insurance (1956) and the General Register Office (1953), showed that the days lost annually from rheumatic diseases ranged from 266 per 100 males for coal miners and 203 for unskilled labourers down to 81 and 59 for clerks and insurance workers respectively. More recently, the Field Unit of the Arthritis and Rheumatism Council (1969) used Ministry of Pensions and National Insurance data for 1963 to show that rheumatic complaints in the male and female insured population of 20.2 million accounted for 29.8 million days of incapacity during the year $(10.3 \%$ of total). Rheumatism was second to bronchitis (39.3 million days) with psychoneurosis and psychosis ( 26.5 million) third.

The first large-scale survey of rheumatic diseases using interviews in this country was carried out in Leigh, Lancashire by Kellgren, Lawrence and Aitken-Swan (1953). A sample of 1619 males and 1896 females over 15 years of age was screened by a medico-social worker; symptoms at the time of questioning were noted in $16 \%$ of males and in $21 \%$ of females while $31 \%$ of males and $34 \%$ of females had had symptoms during the previous five years.

More recently, Tish (1957) reported on 54462 government employees in the United States of America who had received annuities for disabilities between the years 1948 and 1955; diseases of the bones, joints, and muscles accounted for 6880 $(13 \%)$ of these. Unfortunately the definition was too wide to do more than give a general impression of the size of the problem in that country. Brown and Lingg (1961) could find little difference between the sexes in the prevalence rates of complaints among American industrial workers. Rose and Prior (1963) reported that $68 \%$ of 97 Maori patients with rheumatic complaints (excluding disc disease) had non-articular rheumatism or arthralgia.

Surveys of rheumatic complaints have also been made by Kalbak (1953) in Denmark who found a prevalence of $15 \%$ at the time of interview $(32 \%$ at one time or other) and in Holland where de Blécourt (1954) recorded an overall prevalence of $18 \%$ during the previous 12 months based on 3378 interviews (this included rheumatic fever). In a follow-up examination after 10 years de Blécourt et al. (1963) found that the pattern had changed. Rheumatic fever had virtually disappeared but, on the other hand, the prevalence of non-articular rheumatism (fibrositis) among those with complaints had fallen from $46 \%$ to $33 \%$. Articular rheumatism (rheumatoid arthritis and osteoarthrosis) had increased from $57 \%$ to $62 \%$, suggesting that some cases of fibrositis had developed into one of the definitive arthritides.

Reports like these and others described by Bennett and Wood (1968) make it clear that rheumatic diseases and their possible relationship with occupational factors are worth further study and this paper reviews the subject under four main headings:

1. Diagnosis: which diseases and syndromes should be included under the heading 'rheumatic complaints'?

2. Effect: to what extent are sickness absence, change of job, premature retirement, and other manifestations due to the rheumatic complaints to which they are attributed?

3. Cause: is there a relationship between the measurable effects of a complaint in an occupational group and causative factors in the working conditions of that group?

4. Prevention and control: can environmental control at the place of work, health education, personal selection or rehabilitation limit the effects of rheumatic complaints among those already afflicted or reduce their incidence?

In 1960 the Empire Rheumatism Council (now Arthritis and Rheumatism Council) provided a grant to establish an Industrial Survey Unit (I.S.U.) at Edinburgh University under the Directorship of Professor J. J. R. Duthie (Arthritis and Rheumatism Council, 1964); its aim was to study the social and economic effects of rheumatic diseases in industrial populations. Some of the findings of the I.S.U., 
including material not previously published, are discussed in this paper along with reports by others in the field.

\section{Diagnosis}

The nomenclature of rheumatic diseases is difficult to systematize and the resulting confusion has been stressed by Smyth (1960). A patient with any disease, syndrome or label of convenience listed in Table 1 cou'd attend a rheumatic clinic without being out of place. This is no new phenomenon; there has been controversy over nomenclature ever since Hippocrates divided a $\theta \rho$ itis into $\chi \epsilon \iota \rho \alpha \gamma \rho a$

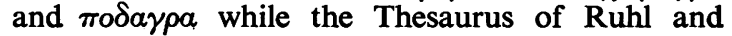
Sokoloff (1965) gives a good indication of the subdivisions of rheumatic diseases and their synonyms at the present time. Rheumatism used to imply some form of discharge and was confused with catarrh until Baillou (1762) distinguished the two by linking rheumatism with arthritis. Subsequently Haygarth (1813) reclassified rheumatism into acute and chronic (i.e., with or without fever).

Today acute rheumatism is more generally regarded as a synonym for rheumatic fever and the World Health Organization (1967-69) placed this alongside cardiac disorders in the International Classification of Diseases (I.C.D.). Gout was classified as metabolic, and sciatica, neuralgia, and brachial neuritis as neurological disorders. More extensive classifications by Blumberg and his colleagues (1964) and Hollander (1966) have shortcomings as they are not universally accepted, particularly outside the field of rheumatology.

Among the most difficult diagnostic problems is that of non-articular rheumatism. Hirsch (1886), writing about medicine in the Middle Ages, said that many of the pains ascribed to rheumatism of the soft tissues were in fact referred from painful lesions of the spinal joints, and many modern rheumatologists share this view. The relationship between surface pain and hyperaesthesia of the skin on the one hand and nipping of the synovial membrane between interarticular facets of the sacroiliac joints or the tension of joint ligaments on the other was discussed by Glover (1960). Later, Hirsch, Ingelmark, and Miller (1963) showed that sensory fibres similar to those found in other joints exist in the intervertebral joint capsule, the capsule of the disc itself, and the ligamenta flava. Ellis (1961) suggested as a clinician that surface pain referred from other sources might be relieved by spraying a cooling agent on the skin. On the other hand, Tichy and Seidel (1969) concluded that muscular rheumatism of the neck and back was probably separate from disc degeneration in the first instance but that the former moved progressively towards the latter as time passed.

Unfortunately, there is a tendency for names to proliferate; a few clear-cut syndromes emerge but

TABLE 1

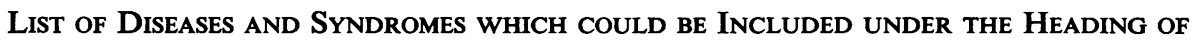
Rheumatic COMPLAINTS

\begin{tabular}{|c|c|c|c|}
\hline $\begin{array}{l}\text { International } \\
\text { classification } \\
\text { no. }\end{array}$ & Name of disease & $\begin{array}{c}\text { International } \\
\text { classification } \\
\text { no. }\end{array}$ & Name of disease \\
\hline $\begin{array}{l}274 \\
305 \cdot 1 \\
351 \\
352 \\
353 \\
355 \\
710^{1,2} \\
711^{1,2} \\
712 \cdot 0^{1,2} \\
712 \cdot 1^{1,2} \\
712 \cdot 2^{1,2} \\
712 \cdot 3^{1,2} \\
712 \cdot 4^{1,2} \\
712 \cdot 5^{1,2} \\
713 \cdot 0^{1,2} \\
713 \cdot 1^{1,2} \\
713 \cdot 2^{1,2} \\
714 \cdot 0^{1,2} \\
714 \cdot 9^{1,2} \\
715^{1,2}\end{array}$ & $\begin{array}{l}\text { Gout } \\
\text { Psychogenic muscle spasm } \\
\text { Trigeminal neuralgia } \\
\text { Brachial neuritis } \\
\text { Sciatica } \\
\text { Neuralgia and neuritis N.O.S. } \\
\text { Acute arthritis due to pyogenic organisms } \\
\text { Acute non-pyogenic arthritis } \\
\text { Juvenile rheumatoid arthritis } \\
\text { Rheumatoid arthritis with splenoadeno- } \\
\text { megaly and leucopenia } \\
\text { Palindromic rheumatism } \\
\text { Other rheumatoid arthritis } \\
\text { Spondylitis ankylopoietica } \\
\text { Chronic rheumatoid nodular fibrositis } \\
\text { Osteoarthritis } \\
\text { Spondylitis osteoarthritica } \\
\text { Traumatic spondylopathy } \\
\text { Other specified forms of arthritis } \\
\text { Other specified form of arthritis } \\
\text { Arthritis unspecified }\end{array}$ & $\left.\begin{array}{l}716 \cdot 0^{1,2} \\
716 \cdot 1^{1,2} \\
717 \cdot 0^{1,2} \\
717 \cdot 1^{1,2} \\
717 \cdot 2^{1,2} \\
717 \cdot 9^{1,2} \\
718^{1,2} \\
721^{2} \\
722^{2} \\
723^{2} \\
724^{2} \\
725^{2} \\
726^{2} \\
728^{2} \\
729^{2} \\
731^{2} \\
734^{2} \\
735^{2} \\
\text { N840 } \\
\text { N848 }\end{array}\right\}$ & $\begin{array}{l}\text { Dermatomyositis } \\
\text { Polymyositis } \\
\text { Lumbago } \\
\text { Scapulohumeral myofibrosis } \\
\text { Torticollis not specified as congenital } \\
\text { Other muscular rheumatism, fibrositis, } \\
\text { and myalgia } \\
\text { Rheumatism unspecified } \\
\text { Osteitis deformans } \\
\text { Osteochondrosis } \\
\text { Other diseases of bone } \\
\text { Internal derangement of joint } \\
\text { Displacement of intervertebral disc } \\
\text { Affection of sacroiliac joint } \\
\text { Vertebrogenic pain syndrome } \\
\text { Other diseases of joint } \\
\text { Synovitis, bursitis, and tenosynovitis } \\
\text { Diffuse diseases of connective tissue } \\
\text { Curvature of spine } \\
\text { Late effects of sprains and strains }\end{array}$ \\
\hline
\end{tabular}

'These diseases are included under the heading 'Arthritis and rheumatism excluding rheumatic fever'.

'Group XIII diseases of musculoskeletal system and connective tissue. 
many merely indicate site, while others, such as polymyalgia or fibrositis, do not even achieve this. Some observers give detailed descriptions of these syndromes but they are often used loosely.

'Polymyalgia rheumatica', described by Barber (1957) and Gordon (1960), may prove to be a clinical entity in its own right but the issue remains in doubt. Benign polyarthritis, discussed by Lawrence and Bennett (1960), may be a synonym but Hart (1969) suggested that some cases develop rheumatoid arthritis or scleroderma.

Kraft, Johnson, and LaBan (1968) discussed 'fibrositis', and earlier Heald (1952) defined it as a localized and clearly defined area of pain with muscular spasm; the symptoms eased after mild exercise only to return after resting. However, opinions expressed at a plenary session of the British Medical Association (1953) suggest that fibrositis is a diagnostic scrap heap. Accordingly, terms such as 'indeterminate pains' or 'pains of undetermined origin', though unsatisfactory to both clinician and epidemiologist, will probably lead to less confusion in the long run than the use of labels which may sound scientific but which are not accurately defined.

When rheumatic diseases cause permanent skeletal changes these can be demonstrated thousands of years after death. Ruffer (1921) described what was probably spondylitis (circa 2000 B.c.) and Boule (1923) described an exostosis of a tibia found in Java which was probably related to trauma.

In modern times radiology of the spine and limbs has been used in numerous surveys to show skeletal change. It was used extensively by Lawrence and Aitken-Swan (1952) and Kellgren and Lawrence (1952). More recently, Lawrence, Bremner, and Bier (1966) have demonstrated the very limited relationship between radiological changes and symptoms in vertebral osteoarthrosis.

Spondylitis ankylopoietica is another cause of backache, and Lawrence (1961a) has described erosive changes in cervical vertebrae typical of rheumatoid arthritis in $\mathbf{3 3}$ out of a random sample of 896 males aged 15 to 65 years. However, Cobb, Merchant, and Rubin (1957) found that $70 \%$ of patients showing radiological changes were completely free of symptoms and Bollet (1969) supported this view.

In the diagnosis of early rheumatoid arthritis of the limbs Cobb and Lawrence (1957) had only limited agreement (110 out of 156) when comparing $x$-ray films on a five-point scale. For this disease, however, additional confirmation can be obtained from serological tests even though the strong correlation is by no means absolute. Kellgren (edited by Duthie and Alexander, 1968) suggested that classical rheumatoid disease, in which $x$-ray and serological changes, polyarthritis, and the non- articular manifestations of rheumatoid disease are all present, probably occurs in about 1 per 1000 persons. Indeed Kellgren and Lawrence (1956) inferred that rheumatoid arthritis could be a loose diagnosis on occasions and Mikkelsen and Dodge (1969) supported this view when they re-examined 402 out of a total of 563 patients with 'possible' rheumatoid arthritis to find that only 107 had retained their original classification while 200 had lost all evidence of the disease.

Similar difficulties can be applied to the diagnostic criteria of most of the diseases listed in Table 1 and the situation can be summarized by saying that a careful history supported by simple clinical examinations will not only reveal those whose work capacity is affected but will suffice in the majority of cases to categorize patients diagnostically for the purposes of field surveys.

On many occasions information published by government departments does not give a detailed breakdown and it is sometimes necessary to accept a less comprehensive list than that in Table 1. 'Diseases of the Bones and Organs of Movement' (Section XIII or numbers 710 to 738 of the I.C.D. is one such grouping; another is "Arthritis and Rheumatism excluding Rheumatic Fever' (numbers 710 to 718 inclusive) ). Statistics about patients attending general practitioners by Logan and Cushion (1958) and Logan (1960) suggest that the two groupings mentioned above will include about $75 \%$ and $55 \%$ respectively of those suffering from the diseases listed in Table 1.

Prevalence studies of rheumatism as a whole, though useful for some purposes, are of limited value, and information about specific rheumatic diseases is also necessary. For such purposes the I.S.U. adopted the following definitions:

(a) Rheumatic complaint: persistent or recurrent musculoskeletal pain without immediate traumatic cause (i.e., injury within six weeks); those with pain at the time of interview or during the previous year were designated 'positives' and those who had only had such symptoms more than a year previously 'intermediates'.

(b) Rheumatoid arthritis: the presence of three of the six clinical criteria recommended by Ropes and his colleagues (1956) (i.e., 'probable' rheumatoid arthritis). These are similar to but not identical with the criteria suggested by King and Cobb (1958).

(c) Osteoarthrosis: clinical evidence of degenerative changes affecting the joints of the limbs. If nodes were present over the distal interphalangeal joints and if there were several joints affected without predisposing injury or deformity, a subgroup of general osteoarthrosis (G.O.A.) was recognized. (These nodes were the subject of a few speculative paragraphs by 
Heberden (1803) and now carry his name.) Those without generalized changes were described as local osteoarthrosis (L.O.A.).

(d) Disc disease: pain in the back or neck which was either recurrent or of prolonged duration $(6+$ weeks) and which could be accurately localized. There also had to be a history of pain radiating along the distribution of a spinal root at some time though not necessarily with every attack. No distinction was made between herniation of the nucleus pulposus and degenerative disc disease.

(e) Chronic tenosynovitis: a history of continuous or intermittent pain on movement of a tendon within its sheath or on pressure over the sheath for at least six weeks.

(f) Chronic bursitis: chronic painful swelling of a bursa, or a history of continuous or recurrent swelling for at least six weeks.
( $g$ ) Gout: a history of severe pain of a joint of sudden onset together with a history of beneficial treatment with uricosuric drugs.

(h) Ankylosing spondylitis and collagen diseases: diagnosed only if the patient had been diagnosed as such in hospital.

(j) Indeterminate rheumatic pain: musculoskeletal pain not falling into one of the above categories which had not been diagnosed as cne of the other rheumatic conditions.

Studies were made in several groups of manual workers and these have been reported in previous papers (Anderson, 1964; Partridge, Anderson, and Duthie, 1964; Partridge, Anderson, McCarthy, and Duthie, 1965; Partridge and Duthie, 1968). The combined results based on 2684 male employees from a range of occupations are summarized in Table 2.

There were 1073 positives ( 307 had symptoms at

TABLE 2

Diagnosis Made on Examination by Age (Male Employees)

\begin{tabular}{|c|c|c|c|c|c|c|c|c|c|c|c|}
\hline \multirow{2}{*}{\multicolumn{5}{|c|}{ Diagnosis }} & \multirow{2}{*}{$C O L$} & \multicolumn{6}{|c|}{ Age (years) } \\
\hline & & & & & & $15-$ & $25-$ & $35-$ & $45-$ & $55+$ & $\begin{array}{c}\text { All } \\
15+\end{array}$ \\
\hline Rheumatoid arthritis & . & . & . & $\because$ & $\mathbf{A}$ & $\underline{0}$ & $\begin{array}{l}2 \\
0 \cdot 42\end{array}$ & $\begin{array}{l}6 \\
1 \cdot 15\end{array}$ & $\begin{array}{l}14 \\
2 \cdot 31\end{array}$ & $\begin{array}{l}9 \\
1 \cdot 58\end{array}$ & $\begin{array}{l}31 \\
1 \cdot 15\end{array}$ \\
\hline General osteoarthrosis & . & . & . & $\%$ & B & - & $\underline{0}$ & $\begin{array}{l}1 \\
0 \cdot 19\end{array}$ & $\begin{array}{l}9 \\
1.49\end{array}$ & $\begin{array}{l}49 \\
8 \cdot 58\end{array}$ & $\begin{array}{l}59 \\
2 \cdot 20\end{array}$ \\
\hline Local osteoarthrosis. . & . & . & . & $\%$ & $\mathrm{C}$ & $\begin{array}{l}5 \\
0.99\end{array}$ & $\begin{array}{l}12 \\
2 \cdot 49\end{array}$ & $\begin{array}{l}26 \\
4.97\end{array}$ & $\begin{array}{l}51 \\
8 \cdot 43\end{array}$ & $\begin{array}{l}70 \\
12 \cdot 26\end{array}$ & $\begin{array}{r}164 \\
6 \cdot 11\end{array}$ \\
\hline All osteoarthrosis & . & . & . & $\%$ & $\mathbf{B}+\mathbf{C}$ & $\begin{array}{l}5 \\
0.99\end{array}$ & $\begin{array}{l}12 \\
2 \cdot 49\end{array}$ & $\begin{array}{l}27 \\
5 \cdot 16\end{array}$ & $\begin{array}{l}60 \\
9.92\end{array}$ & $\begin{array}{l}119 \\
20 \cdot 84\end{array}$ & $\begin{array}{l}223 \\
8 \cdot 31\end{array}$ \\
\hline Disc disease ... & . & . & . & $\%$ & $\mathbf{D}$ & $\begin{array}{l}11 \\
2 \cdot 18\end{array}$ & $\begin{array}{l}38 \\
7 \cdot 90\end{array}$ & $\begin{array}{l}67 \\
12 \cdot 81\end{array}$ & $\begin{array}{l}103 \\
17 \cdot 02\end{array}$ & $\begin{array}{l}108 \\
18 \cdot 91\end{array}$ & $\begin{array}{l}327 \\
12 \cdot 18\end{array}$ \\
\hline \multicolumn{2}{|c|}{ Vague pains in back and neck } & . & . & $\%$ & $\mathbf{E}$ & $\begin{array}{l}46 \\
9 \cdot 13\end{array}$ & $\begin{array}{l}86 \\
17 \cdot 88\end{array}$ & $\begin{array}{l}115 \\
21.99\end{array}$ & $\begin{array}{l}122 \\
20 \cdot 17\end{array}$ & $\begin{array}{l}109 \\
19 \cdot 09\end{array}$ & $\begin{array}{l}478 \\
17 \cdot 81\end{array}$ \\
\hline \multirow{2}{*}{$\begin{array}{l}\text { All axial pains } \\
\text { Vague pains of limbs }\end{array}$} & . & . & . & $\%$ & $\mathbf{D}+\mathbf{E}$ & $\begin{array}{l}57 \\
11 \cdot 31\end{array}$ & $\begin{array}{l}124 \\
25 \cdot 78\end{array}$ & $\begin{array}{l}182 \\
34 \cdot 80\end{array}$ & $\begin{array}{l}225 \\
37 \cdot 19\end{array}$ & $\begin{array}{l}217 \\
38 \cdot 00\end{array}$ & $\begin{array}{l}805 \\
29.99\end{array}$ \\
\hline & . & . & . & $\%$ & $\mathbf{F}$ & $\begin{array}{l}24 \\
4 \cdot 76\end{array}$ & $\begin{array}{l}51 \\
10 \cdot 60\end{array}$ & $\begin{array}{l}72 \\
13 \cdot 77\end{array}$ & $\begin{array}{l}90 \\
14 \cdot 88\end{array}$ & $\begin{array}{l}58 \\
10 \cdot 16\end{array}$ & $\begin{array}{l}295 \\
10.99\end{array}$ \\
\hline \multirow{2}{*}{$\begin{array}{l}\text { All vague pain } \quad . \\
\text { Other rheumatic diseases }\end{array}$} & . & - & . & $\%$ & $E+F$ & $\begin{array}{l}70 \\
13 \cdot 89\end{array}$ & $\begin{array}{l}137 \\
28 \cdot 48\end{array}$ & $\begin{array}{l}187 \\
35 \cdot 76\end{array}$ & $\begin{array}{l}212 \\
35 \cdot 04\end{array}$ & $\begin{array}{l}167 \\
29 \cdot 25\end{array}$ & $\begin{array}{l}773 \\
28 \cdot 80\end{array}$ \\
\hline & . & $\cdots$ & . & $\%$ & $\mathbf{G}$ & $\begin{array}{l}4 \\
0 \cdot 79\end{array}$ & $\begin{array}{l}17 \\
3 \cdot 53\end{array}$ & $\begin{array}{l}18 \\
3.44\end{array}$ & $\begin{array}{l}27 \\
4 \cdot 46\end{array}$ & $\begin{array}{l}23 \\
4.03\end{array}$ & $\begin{array}{l}89 \\
3 \cdot 32\end{array}$ \\
\hline Unknown (not examined) & . & . & . & $\%$ & $\mathbf{H}$ & $\underline{0}$ & $\underline{0}$ & $\begin{array}{l}1 \\
0 \cdot 19\end{array}$ & $\begin{array}{l}1 \\
0 \cdot 17\end{array}$ & $\begin{array}{l}1 \\
0 \cdot 18\end{array}$ & $\begin{array}{l}3 \\
0 \cdot 11\end{array}$ \\
\hline \multicolumn{4}{|c|}{ All positives (symptoms now or in past year) } & $\%$ & $\mathbf{J}$ & $\begin{array}{l}73 \\
14 \cdot 48\end{array}$ & $\begin{array}{l}162 \\
33 \cdot 68\end{array}$ & $\begin{array}{l}237 \\
45 \cdot 32\end{array}$ & $\begin{array}{l}309 \\
51.07\end{array}$ & $\begin{array}{l}292 \\
51 \cdot 14\end{array}$ & $\begin{array}{l}1073 \\
39.98\end{array}$ \\
\hline All intermediates & . & . & . & $\%$ & $\mathbf{K}$ & $\begin{array}{l}17 \\
3 \cdot 37\end{array}$ & $\begin{array}{c}40 \\
8 \cdot 32\end{array}$ & $\begin{array}{l}63 \\
12 \cdot 05\end{array}$ & $\begin{array}{l}90 \\
14 \cdot 88\end{array}$ & $\begin{array}{l}116 \\
20 \cdot 32\end{array}$ & $\begin{array}{l}326 \\
12 \cdot 15\end{array}$ \\
\hline \multirow{2}{*}{\multicolumn{2}{|c|}{$\begin{array}{l}\text { All with rheumatic complaints } \\
\text { intermediates) } \ldots \\
\text { Patients with multiple diagnoses }\end{array}$}} & $\begin{array}{l}\text { (po } \\
\ldots\end{array}$ & $\begin{array}{l}\text { ives } \\
\text {. }\end{array}$ & $\begin{array}{r}\text { and } \\
\% \\
\%\end{array}$ & $\begin{array}{l}\text { A to } \mathbf{H} \\
\text { incl. or } \\
\mathbf{J}+\mathbf{K}\end{array}$ & $\begin{array}{l}90 \\
17 \cdot 86\end{array}$ & $\begin{array}{l}202 \\
42 \cdot 00\end{array}$ & $\begin{array}{l}300 \\
57 \cdot 36\end{array}$ & $\begin{array}{l}399 \\
65.95\end{array}$ & $\begin{array}{l}408 \\
71 \cdot 45\end{array}$ & $\begin{array}{l}1399 \\
52 \cdot 12\end{array}$ \\
\hline & & . & . & $\%$ & & $\underline{0}$ & $\begin{array}{l}4 \\
0 \cdot 83\end{array}$ & $\begin{array}{l}5 \\
0.96\end{array}$ & $\begin{array}{l}17 \\
2 \cdot 81\end{array}$ & $\begin{array}{l}18 \\
3 \cdot 15\end{array}$ & $\begin{array}{l}44 \\
1 \cdot 64\end{array}$ \\
\hline \multicolumn{3}{|c|}{ Negatives (including 3 false positives) } & . & $\%$ & $\mathbf{L}$ & $\begin{array}{l}414 \\
82 \cdot 14\end{array}$ & $\begin{array}{l}279 \\
58 \cdot 00\end{array}$ & $\begin{array}{l}223 \\
42 \cdot 64\end{array}$ & $\begin{array}{l}206 \\
34.05\end{array}$ & $\begin{array}{l}163 \\
28 \cdot 5\end{array}$ & $\begin{array}{l}1285 \\
47 \cdot 88\end{array}$ \\
\hline \multicolumn{5}{|c|}{ Total interviewed on which $\%$ are based .. } & $\mathbf{J}+\mathbf{K}+\mathbf{L}$ & 504 & 481 & 523 & 605 & 571 & 2684 \\
\hline
\end{tabular}


interview) and 326 intermediates including 17 men who initially denied that they had rheumatism but were later found to have had symptoms. The remaining 1285 were negatives. The prevalence of positives increased with age up to 54 years but did not increase thereafter while the proportion of intermediates continued to increase above the age of 55 years.

Osteoarthrosis increased with age; so did disc disease, though less markedly above 55 years, but the prevalence rates for both these diseases (and particularly for G.O.A.) were lower than those recently reported by Lawrence (1969a, b). This may be due to the fact that some ill-defined pains of younger men become disc disease, osteoarthrosis or rheumatoid arthritis in later life and studies using radiological or serological tests may be able to anticipate some of these developments.

Other labelled rheumatic diseases in the I.S.U. studies were mainly chronic tenosynovitis or chronic bursitis; there were, however, three cases of gout, two of ankylosing spondylitis, and one each of psoriatic arthritis and scleroderma. The I.S.U. finding that $55 \%$ of all those with complaints had 'vague' pains was nearer the rate of $52 \%$ reported by Nelson and Lancaster (1959) than that of $45 \%$ reported by Kellgren and his colleagues (1953).

\section{Severity of rheumatic disease}

The diagnoses and the degrees of functional disability are as shown in Table 3. There were 1105 men $(79 \%$ of those with symptoms) who had such minimal impairments that they did not cause any disability. Of the remaining 291, 207 were over the age of 45 years. Severity may have increased with advancing years; alternatively, older men with severe disabilities may have been kept on more readily than younger men who had not been with firms long enough to warrant sympathetic consideration. The striking thing was that $97 \%$ of the cases of indeterminate pain had little appreciable disability whereas the equivalent rates for men with definitive types of rheumatic diseases ranged from $42 \%$ for those with rheumatoid arthritis up to $64 \%$ for men with diseases such as chronic tenosynovitis and bursitis.

\section{Effects of rheumatic disease}

\section{Sickness absence}

Rheumatic diseases seldom produce dramatic or sudden disability; thus Moore (1969) found that only two illnesses out of a total of 68 treated by naval surgeons as emergencies among deep-sea fishermen were 'locomotor'. Nevertheless sickness absence is an important effect of rheumatic disease. A specific study was made by McGregor (1960), who looked at sickness patterns among workers in northern Scotland; absence because of rheumatism in those over 50 years of age was higher in forestry workers than among office workers.

More recently, the Arthritis and Rheumatism Council (1969) reported that the annual absence rates ascribed to rheumatic diseases in men over 25 years ranged from 3.7 days for dockers and coal miners down to 1.6 for civil servants and 0.6 for electronic assembly workers. These were crude rates but standardized absence ratios (S.A.R.) were used

TABLE 3

Rheumatic Complaints and Functional Disability

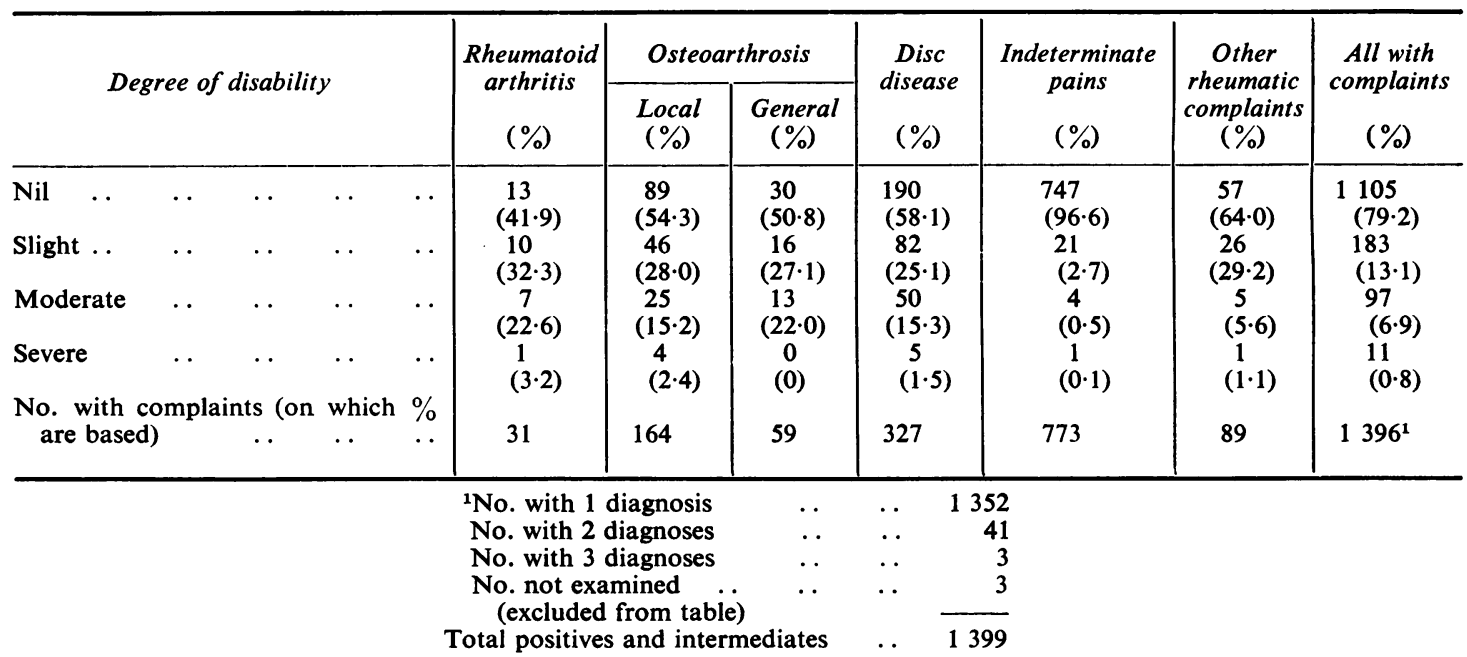


by the I.S.U. (Anderson and Duthie, 1963) when studying different occupational groups. These were calculated from the formula:

S.A.R. =

$$
\text { Observed number of weeks of absence }
$$$$
\text { Expected number of weeks of absence }
$$

using age-specific rates to calculate the expected values. The use of these ratios confirmed that high sickness absences from rheumatic causes were related to heavy occupations. Thus among foundry workers Partridge, Anderson, McCarthy, and Duthie (1968) found that the S.A.R. varied from 281 and 158 for furnacemen and general labourers respectively down to 7 and nil for dressers and pattern makers.

It is not always possible to be certain that all absences ascribed to a disease are in fact caused by it. Doctor, patient or both may be influenced by previous episodes of rheumatism and aches or pains, perhaps merely manifestations of a febrile illness, may be designated 'rheumatic' in one known to be susceptible thus giving incorrect bias. One method of overcoming this problem was used by Taylor (1968) when the industrial medical officer checked the causes of absence. An alternative method by direct communication with family doctors was found by the I.S.U. team to be difficult to put into practice. Even if the stated cause is taken at its face value, however, some checks are still possible by comparing sickness absence in affected and non-affected groups of workers. Thus the Figure shows the rates of sickness absence per 100 workers. On the right are shown the rates from illness other than rheumatism for positives and negatives; rheumatic sickness rates for the positives are shown on the left.

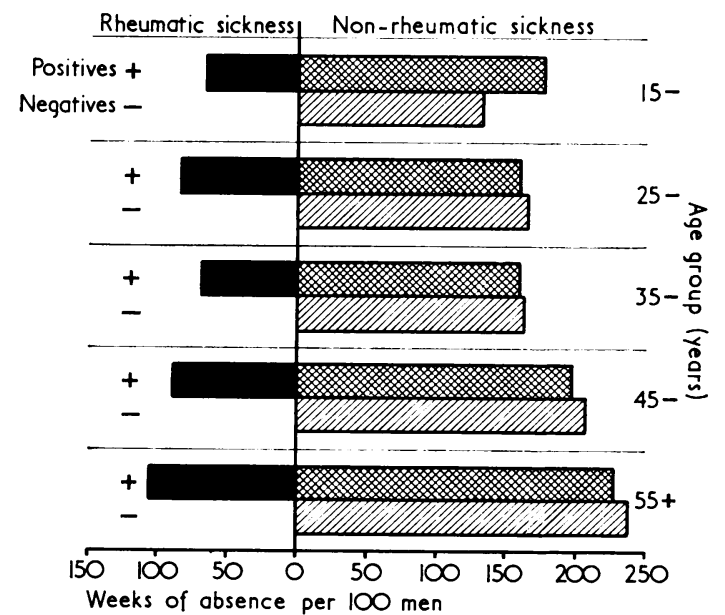

FIGURE. Sickness absence for positives and negatives.
Negatives had more absence due to non-rheumatic illnesses than positives at all ages over 25 years; this was more marked in the oldest workers. Some substitution may therefore have taken place, especially in later life when rheumatic labels became more firmly attached. At no age, however, was the total sickness absence (i.e., due to rheumatic plus non-rheumatic diseases) in positives less than that for negatives. This indicates that absence carrying a rheumatic label occurred in addition to the other sicknesses which affected both rheumatic and nonrheumatic subjects.

These findings have been noted consistently in several occupations but other factors also affect sickness absence. Taylor (1967a, and b) found that sickness spells from all causes followed a negative binomial rather than a Poisson distribution unrelated to occupation or length of service. Day workers had more spells and lost more days than shift workers but spells were shorter in day than in shift workers. His reports did not deal specifically with rheumatic diseases but Vaceva (1966), observing patterns among Bulgarian industrial workers, has expressed the opinion that absence due to chronic diseases (including rheumatic) was high among workers on prolonged night shift. Short-term absences (1 to 2 days) constitute another important cause of lost work (Froggatt, 1970). It seems likely that those with an established diagnosis, such as chronic rheumatism, would be candidates for this sort of absence in addition to longer spells which require the support of a medical certificate.

Chronicity, particularly among established cases of backache, has been emphasized by Horal (1969) who reported on a comparative study (carried out in Gothenberg, Sweden) on 212 probands sick-listed for back disorders. They had as many standard defects of the spine and previous attacks of backache as controls matched for age, sex, and sickness benefit category but the relapse rate was higher among the probands.

Memory presents another problem unless each spell of sickness can be checked by an independent observer. Beall and Cobb (1961) compared the estimates made by 274 craftsmen of the number of days on which joint swelling was present with their own observations over a six-month period. The workers' estimates were very slightly lower than those observed by periodic examinations for men who had swelling for less than $30 \%$ of the time but higher for those with swelling for over $40 \%$ of the time. Earlier Stocks (1949), using general practitioner records, showed that estimates based on memory tended to shorten sickness periods; however Cobb and his colleagues (1956), referring particularly to rheumatic symptoms, felt that inconsistencies were less liable to occur if the history was taken by a single observer. 
Demands for medical care

Other effects of rheumatic complaints are reflected in the demands made for medical care. Such demands do not always result in absence or an insurance claim. Even so a proportion of those under medical care and still at work may nevertheless have impaired efficiency.

Table 4 shows levels of medical care and sickness absence for different causes among the 1396 affected workers in the I.S.U. studies. The highest rate for self medication was among those with disc disease (48\%); this contrasted with $26 \%$ (278 out of 1096 ) with all other types of rheumatic disease $(P<0.001)$. Those with disc disease also made the highest demands on their general practitioners. It is, of course, possible that complaints which patients present to doctors may appear to the latter to be of secondary importance. Even rheumatoid arthritis has been shown to take second place in the diagnostic hierarchy by Cobb, Anderson, and Bauer (1953) studying diagnoses on death certificates.

General practitioners themselves claim that less than $10 \%$ of their registered patients consult with rheumatic disease. Logan and Cushion (1958) reported that $8.9 \%$ of men aged 15 to 64 years attended in the course of an observation year with 'diseases of bones and organs of movement'. Later Logan (1960) observed that annual consultation rates for arthritis and rheumatism were higher for manual than for non-manual workers, ranging from $9.4 \%$ for semiskilled manual workers to $5.2 \%$ for shop assistants and $3.7 \%$ for those in the managerial grades. These are higher than the figures of Partridge and Knox (1969) in a survey of seven practices with an average of $3.9 \%$ of males aged $15+$ consulting on account of a rheumatic complaint. In another study Dillane, Fry, and Kalton (1966), recording acute backache, noted that $7 \cdot 4 \%$ of the practice population consulted over a four-year period; the annual inception rates were: males $2.4 \%$, females $2.0 \%$.

Referrals to hospital shown in Table 4 were highest for those with disc disease; they also had a comparatively high admission rate but the highest admission rate was for rheumatoid arthritis and these two conditions are also those which stand out in studies of admissions to wards (Duthie, 1962; Hollander, 1966).

Sixty-one percent of men with rheumatoid arthritis and $46 \%$ of those with disc disease had had at least one spell of absence lasting three weeks. Furthermore, $168(53 \%)$ out of the 317 men who had ever had such prolonged spells of absence were suffering from one of these two conditions. The average age of those with rheumatoid arthritis was $49 \cdot 7$ years (S.D. 8.5) while that for men with disc disease was 47.9 years (S.D. 11.2); these averages are both lower than in men with osteoarthrosis $(52 \cdot 4$ years, S.D. $10 \cdot 1)$, among whom only $24 \%$ had had periods of prolonged absence. Disc disease led to a high sickness absence in the previous year (143 weeks per 100 men in the survey) and the number of men involved (81) accounted for $46 \%$ of those who

TABLE 4

Medical Care for Rheumatic Diseases (Percentages per 100 Men Affected)

\begin{tabular}{|c|c|c|c|c|c|c|c|c|}
\hline \multirow{2}{*}{ Medical care } & \multirow{2}{*}{$\begin{array}{c}\text { Rheumatoid } \\
\text { arthritis }\end{array}$} & \multicolumn{2}{|c|}{ Osteoarthrosis } & \multirow{2}{*}{$\begin{array}{c}\text { Disc } \\
\text { disease }\end{array}$} & \multicolumn{2}{|c|}{$\begin{array}{c}\text { Indeterminate } \\
\text { pains }\end{array}$} & \multirow{2}{*}{$\begin{array}{l}\text { All other } \\
\text { rheumatic } \\
\text { diseases }\end{array}$} & \multirow{2}{*}{$\begin{array}{l}\text { All with } \\
\text { complaints }\end{array}$} \\
\hline & & General & Local & & Back & Limbs & & \\
\hline 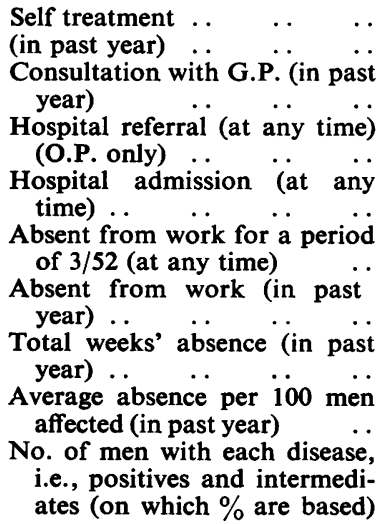 & $\begin{array}{c}8 \\
(25 \cdot 8) \\
12 \\
(38 \cdot 7) \\
8 \\
(25 \cdot 8) \\
9 \\
(29 \cdot 0) \\
19 \\
(61 \cdot 3) \\
7 \\
(22 \cdot 6) \\
91 \\
91 \\
293 \cdot 5\end{array}$ & $\begin{array}{c}19 \\
(32 \cdot 2) \\
17 \\
(28 \cdot 8) \\
13 \\
(22 \cdot 0) \\
2 \\
(3 \cdot 4) \\
14 \\
(23 \cdot 7) \\
6 \\
(10 \cdot 2) \\
19 \\
\\
32 \cdot 2\end{array}$ & $\begin{array}{c}60 \\
(36 \cdot 6) \\
58 \\
(35 \cdot 4) \\
46 \\
(28 \cdot 0) \\
7 \\
(4 \cdot 3) \\
45 \\
(27 \cdot 4) \\
28 \\
(17 \cdot 1) \\
\\
157 \\
\\
95 \cdot 7\end{array}$ & $\begin{array}{l}156 \\
(47 \cdot 7) \\
140 \\
(42 \cdot 8) \\
121 \\
(37 \cdot 0) \\
39 \\
(11 \cdot 9) \\
149 \\
(45 \cdot 6) \\
81 \\
(24 \cdot 8) \\
\\
467 \\
\\
142 \cdot 8\end{array}$ & $\begin{array}{l}109 \\
(22 \cdot 8) \\
109 \\
(22 \cdot 8) \\
57 \\
(11 \cdot 9) \\
10 \\
(2 \cdot 1) \\
62 \\
(13 \cdot 0) \\
43 \\
(9 \cdot 0) \\
137 \\
28 \cdot 7\end{array}$ & $\begin{array}{c}68 \\
(23 \cdot 1) \\
40 \\
(13 \cdot 6) \\
26 \\
(8 \cdot 8) \\
4 \\
(1 \cdot 4) \\
19 \\
(6 \cdot 4) \\
8 \\
(2 \cdot 7) \\
\\
31 \\
\\
10 \cdot 5\end{array}$ & $\begin{array}{l}28 \\
(31 \cdot 5) \\
27 \\
(30 \cdot 3) \\
28 \\
(31 \cdot 5) \\
14 \\
(15 \cdot 7) \\
26 \\
(29 \cdot 2) \\
11 \\
(12 \cdot 4) \\
58 \\
5 \\
65 \cdot 2\end{array}$ & $\begin{array}{l}434 \\
(31 \cdot 1) \\
390 \\
(27 \cdot 9) \\
285 \\
(20 \cdot 4) \\
82 \\
(5 \cdot 9) \\
317 \\
(22 \cdot 7) \\
178 \\
(12 \cdot 8) \\
922 \\
66 \cdot 0\end{array}$ \\
\hline
\end{tabular}

${ }^{1}$ See footnote to Table 3. 
had been absent from any rheumatic cause. Rheumatoid arthritis also caused a high absence rate but 64 of the 91 weeks were lost by only three men.

\section{Change of job}

Prolonged or repeated sickness absences force a man to change his job, and Anderson, Duthie, and Moody (1962) found that disc disease was the rheumatic complaint most likely to have this effect in miners. However, caution is needed in interpreting surveys of changed jobs particularly as rheumatism fulfils the criteria of medical respectability suggested by Parsons (1951) more than mere physical or mental inadequacy. Lindén (1969) made a detailed study of five non-sedentary workers who were repeatedly off work compared with five controls with normal sickness experience; he suggested that the repeaters were exposed to effort beyond their physical capacity.

One of the studies carried out by I.S.U. examined the work histories of 201 manual workers from a naval dockyard including 30 who stated on questioning that they had changed jobs because of rheumatic diseases. The other 171 had either been absent from work for at least three weeks because of a rheumatic complaint or had sought medical advice within the past year. These were matched by age, occupation, and place of work (i.e., indoor or outdoor, etc.) with an equal number who had never had rheumatic symptoms at any time. The total number of job changes in the two groups since leaving school is shown in Table 5 and the close similarity between them is a reasonably clear indication that factors other than rheumatic complaints probably contributed to the changes.

Effects on home life

Other social effects were recorded (Anderson,

TABLE 5

Total Number of Jobs Since Starting Work (201 Matched Pairs of Dockyard EMPloyees)

\begin{tabular}{c|c|c}
\hline No. of jobs & Selected positives $^{1}$ & Selected negatives $^{1}$ \\
\hline 1 & 6 & 11 \\
2 & 30 & 31 \\
3 & 42 & 41 \\
4 & 47 & 41 \\
5 & 25 & 20 \\
$6-10$ & 32 & 35 \\
11 & 1 & 11 \\
Uncertain & 18 & 21 \\
\hline Total in samples & 201 & 201 \\
\hline
\end{tabular}

${ }^{1}$ for definition see text.
1964) in the 201 matched pairs of dockyard workers mentioned in the previous section. Standards of housing were similar with $16(8 \%)$ of both the selected positives and the matched negatives living in houses without baths ( 7 of each group had only a cold tap).

There were 172 married positives compared with 154 negatives; and eight positives were either widowed or separated as opposed to 12 negatives. Of the 172 wives currently living with the selected positives there were $41(24 \%)$ who went out to work while 154 wives of the control group contained 39 $(25 \%)$ who were working. There was apparently no suggestion, therefore, that the wives of those who were fairly severely affected by rheumatism were being forced to seek employment.

Only four $(2 \%)$ of the selected positives were currently registered as disabled persons because of rheumatism and a further one had been so registered in the past. In both samples there were nine men $(4 \%)$ who were currently registered or who had been registered in the past for some other disability.

Other studies have considered social effects from different points of view; the consequences of rheumatoid arthritis, for instance, may be particularly severe to the relatively small number who are badly affected. Duthie, Thompson, Weir, and Fletcher (1955) and Duthie and his colleagues (1964) emphasized the importance of social factors affecting rehabilitation in such patients and the usefulness of a social worker. Lawrie (1960) discussed the importance of travelling distance between home and work and Ansell (1969) suggested that suitable cases might merit the provision of personalized motor transport. Educating the family can also be a great help in getting those affected by chronic locomotor disease to help themselves. Oakes and his colleagues (1970) found that family expectations in relation to supporting splints led to a greater compliance by patients than among those whose family did not expect the appliance to be used.

\section{Long-term disability}

Men registered as disabled and unemployed for three months or more were studied by Anderson, Duthie, and Moody (1963). Rheumatic complaints, present in $56(74 \%)$ of the 76 men examined, were the main disability in $13(17 \%)$ of them. Richardson (1956) found that $18(20 \%)$ of 91 unemployed men with disabilities were suffering from either arthritis or 'backache'. In neither of these two studies was it suggested that rheumatic complaints alone played a dominant part in prolonged unemployment. Indeed Anderson and his colleagues found that 41 out of the 76 disabled men had been off work for at least two years; these comprised $30(54 \%)$ out of 56 with rheumatic complaints and $11(55 \%)$ out of 20 without. Back pain appeared an important cause of 
prolonged unemployment to the men themselves and White (1966) also stressed its importance; he found that $10 \%$ of men with low back pain receiving workmen's compensation in Ontario had been disabled for more than six weeks.

In studies like those there is always a danger that fear of social or financial sanctions may lead to exaggerated stories of disability. Lack of knowledge, however, is not much of a problem as 65 cases of motor impairment studied by Jefferys and her colleagues (1969) were fairly knowledgeable about their diagnoses; in $59(90 \%)$ there was complete agreement with the diagnosis given by the general practitioners.

\section{Cause}

Wells (1969), in his Rammazzini oration, discussed in general the "hard life of people who must work for a living' and rheumatic diseases are among the many that have been linked with manual labour.

Occupational factors in the aetiology of bursitis, tenosynovitis, traumatic arthritis, and similar conditions are reasonably obvious. Terms like 'housemaid's knee', 'policeman's heel', 'weaver's bottom', and 'telegraphist's wrist' all have occupations incorporated in them. Such lesions are commonly associated with the occupation used in the designation but they need not be linked exclusively with employment; tennis elbow, golfer's shoulder, and baseball player's glass arm, though 'industrial' in professional sportsmen, commonly affect amateurs who overindulge after prolonged inactivity.

There is also general agreement with Ray (1932) that pneumatic tools may cause damage to the cartilage of the wrists, elbows, and shoulders. Increased atmospheric pressure is another hazard, and McCallum, Stanger, Walder, and Paton (1954) associated this with bilateral avascular necrosis of the femoral heads. On the other hand, some diseases, apparently related to the musculoskeletal system, have no direct traumatic background; for instance, the shoulder-hand syndrome may co-exist with a coronary infarct (Steinbrocker, Spitzer, and Friedman, 1948).

General acceptance that chronic irritation can and often does produce oeteoarthrosis (Abrams, 1960) leads naturally to the concept that prolonged heavy work may do likewise. Pommer (1927) linked osteoarthrosis with heavy manual labour and Frenkil (1959), reviewing the evidence, accepted that trauma could set the stage for degenerative changes. Hippocrates regarded it as a disease of the elderly (Adams, 1886), a view shared by Ecker (1843) and later accepted by Keefer, Parker, Myers, and Irwin (1934). Sokoloff (1966) discussed biochemical and other factors and Saville and Dickson (1968), in a study of 121 men and women with osteo- arthrosis of the hips, could not relate severity with obesity. Falconnet and Vignon (1968) also studied 200 cases of hip disease and suggested both weight and trauma among many predisposing factors.

Secondary or localized osteoarthrosis was distinguished from the primary or generalized form (G.O.A.) by Kellgren and Moore (1952). Stecher (1940) observed a lower prevalence of the latter in negroid Americans than in whites and subsequently (Stecher, 1955) suggested that liability to Heberden's nodes was a dominant gene in females and recessive in males.

Lawrence (1961b), surveying 69 male cotton operatives aged 45 and over, observed that $38 \%$ had Heberden's nodes compared with $12 \%$ among controls. More recently, Kellgren, Lawrence, and Bier (1963) postulated a familial cause for nodal G.O.A. while Lawrence (1969b) distinguished between nodal G.O.A. (common in females) and non-nodal G.O.A. (common in males). The difference between local (secondary) osteoarthrosis and non-nodal G.O.A. involving three or more joints (or even five and more joints) seems a fine one since heavy manual labour could traumatize more than two joints.

Back pain has also been linked with heavy occupations though, of course, G.O.A. can include degenerative changes in the spine (Kellgren and Lawrence, 1958). Lawrence (1955) related disc degeneration and heavy lifting or back injuries and Bremner, Lawrence, and Miall (1968) found that, though lumbar disc disease had the same prevalence in Jamaicans and Caucasians, cervical lesions were common in the former, possibly because of the cariage of head loads. In another occupational field Matthews (1964a, b) has described how tractor seats and pneumatic tyres affect the spines of the drivers.

Caplan, Freedman, and Connelly (1962) did not think that disc degeneration was due solely to ageing. They found a relationship between narrowing of the disc spaces and previous injury but not between disc changes and heavy work without injury. Earlier Bradshaw (1957), while accepting that occupational stress increased symptoms, could find no evidence that it predisposed to the lesions of cervical spondylosis. Boasson and his colleagues (1969) emphasized the inevitability of these conditions and that treatment could not be shown to influence their course, and Bull, El Gammal, and Popham (1969) suggested a genetic basis for spondylosis.

Back pain in young fit men has long been recognized as important by the armed Forces and diagnosing 'hysteria' is discouraged even if the cause of pain is not obvious (War Office, 1959). Among civilians Diveley and Oglevie (1956) studied 6523 prospective employees with low back pain and subsequently Diveley, Kiene, and Meyer (1956) 
reviewed 3587 employees with pain of at least three years' duration. There were $83(2 \%)$ with prolapsed discs and $495(14 \%)$ had unexplained symptoms; $1108(31 \%)$ had congenital abnormalities and 1897 $(53 \%)$ had lumbosacral or sacroiliac strain. Not all of those with abnormalities complained of pain, suggesting that other factors predisposed to symptoms. Christian (1968) also suggested that osteophytes might give extra rigidity and thus reduce symptoms.

Ellman and Shaw (1950) found higher rates of emotional stress, neurotic traits, and family history of neurosis or psychosis in 159 cases of non-articular rheumatism than in 58 controls. This was supported by Scott (1960) and others in general practice; of 314 patients suffering from rheumatic disease in one year, $18 \%$ had some emotional instability contrasted with $14 \%$ among the other 2523 seeking medical advice. This trend was more marked in females, and Erkrath and Strauch (1968) suggested that back pain diminished efficiency among females. Collette and Ludwig (1968), however, did not consider that those with low back pain were 'poor worker types'.

The relationship between symptoms from disc disease and weight bearing were also discussed by Arnott and Grieve (1969) and by Troup, Roantree, and Archibald $(1970 \mathrm{a}, \mathrm{b})$ in relation to forces operating during rotational movements and lifting while stooping. However, accurate measurements of the effects of prolonged effort on the different components of an intervertebral disc and its related vertebrae are difficult, and Movin (1967) observed no difference radiologically in 24 out of 35 cases of disc disease between the recumbent and upright positions. This is perhaps hardly surprising since Hirsch (1966) observed that a weight of $100 \mathrm{~kg}$ on vertebrae caused compression of a damaged disc by 1.5 to $2 \mathrm{~mm}$ and lateral bulging of $1 \mathrm{~mm}$. Davis (1959) measured changes in intra-abdominal pressure by using swallowed balloons attached to manometers; however, any attempt to relate such pressure changes to effort by the lumbar muscles would have to be interpreted with caution, particularly as Beattie (1953) has suggested that backache associated with dyspepsia might be caused by abnormal tension in the walls of a viscus.

In summary, it can be said that the relatively high prevalence of disc disease among heavy manual workers is strong presumptive evidence of a causal relationship but this is less clear-cut than in the case of osteoarthrosis of the limbs.

Less certain are the links between muscular effort at work and pains of indeterminate origin. If it is accepted that many vague pains in the limbs and back may be precursors of the degenerative changes associated with osteoarthrosis and disc disease respectively, then a relationship should be demonstrable. The results published by the survey units of the Arthritis and Rheumatism Council in Edinburgh and Manchester indicate that though sickness absence rates do seem to be related to heavy jobs the relationship with complaint rates is more doubtful. Coal miners certainly have higher complaint rates for rheumatic diseases as a whole than workers in less strenuous industries (Lawrence and AitkenSwan, 1952; Anderson et al., 1962) but these stem from osteoarthrosis, disc disease, and chronic bursitis rather than from indeterminate pains, findings which have been confirmed by Lockshin and his colleagues (1969) in West Virginia. Furthermore, complaint ratios (standardized for age) in 18 widely ranging occupations showed no obvious correlation with heavy jobs (Anderson and Duthie, 1963).

The aetiology of rheumatoid arthritis is even more complex. Dahlberg and Grubb (1951) studied 292 cases and 296 of neurosis. They could find no differences in social conditions, nor could LewisFaning (1950) who also considered infection as a possible cause with mainly negative conclusions; he suggested a familial basis and noted that pregnancy had a beneficial effect. Endocrine links were also discussed by Gill (1968) and Spiera and Plotz (1969) in relation to 3014 women using antiovulatory drugs, while Bole, Friedlaender, and Smith (1969) found symptoms lessened when contraceptives were discontinued.

Kellgren (1964) discussed the genetic basis for rheumatoid arthritis and Bremner (1961), studying 1794 adults living in Wensleydale, found a lower complaint rate among those born in the Dale than among new residents (39\% and $47 \%$ respectively). However, there could have been either genetic or environmental reasons or a mixture of the two.

Miall, Ball, and Kellgren (1958) studied urban and rural populations in Wales using sheep cell tests and radiology and found an earlier onset of the disease among town dwellers, but Miall (1955) could find little difference between miners and nonminers in 9430 males aged 15 years and over. Claussen (1955) supported the genetic basis (14 out of 43 pairs of identical twins both had rheumatic disorders while the figures for non-identical twins were 2 out of 30). However, Meyerowitz, Jacox, and Hess (1968) did not confirm this and Cobb and his colleagues (1969) concluded that there was no evidence of familial transmission.

Cobb, Miller, and Wieland (1959) suggested a possible relationship between divorce and rheumatoid arthritis and Kidd and Park (1960) noted that inception rates were higher in males than in single females but highest among married females, while Cobb and his colleagues (1969) suggested that symptoms could be brought on by conflict. Earlier Lowman and his colleagues (1954) had indicated that marital problems reduced the likelihood of successful rehabilitation and Mueller, Lefkovits, 
Bryant, and Marshall $(1960 ; 1961)$ maintained that rheumatoid patients had more 'contained hostility' than normal. Moos (1964), in a review article, suggested that rheumatoid subjects were selfsacrificing, masochistic, conforming, self-conscious, shy, inhibited, perfectionistic, and interested in sports and games. Scotch and Geiger (1962), however, were more guarded, being concerned about inconsistent definitions and lack of comparable material.

Cobb (1965) and Kellgren (1966) agreed that the aetiology was multifactorial but Duthie, Stewart, Alexander, and Dayhoff (1967) renewed interest in the idea of an infective basis by observing diphtheroids in joint fluid; Hill (1968) commented that if micro-organisms played any role it was likely to be indirect and mediated through a disturbed immune response.

The conclusion from all the above is that if some factor related to employment, such as undue muscular effort, psychological stress or climatic extremes, contributes to systemic upset (perhaps by affecting the reaction between infection and immune response) then the possibility that this could precipitate the onset of rheumatoid manifestations cannot be excluded absolutely. However, the concensus of opinion at present is that there is no proven connexion between conditions at work and the aetiology of rheumatoid arthritis.

Gout is another disease in which genetic background and metabolic upset are linked (Scudamore, 1823). Smyth $(1957 ; 1966)$ confirmed this by family studies and included alcohol as an additional factor. This view is generally shared though Hench (1948) and Scott (1969) both question the importance of moderation as a therapeutic measure. Acheson (1969) was unable to show a relationship between serum uric acid and social class ${ }^{1}$ but occupations where alcohol consumption is potentially high (including stressful situations in any job) could probably hasten the onset of gout in a susceptible individual especially as Kasl, Cobb, and Brooks (1968) observed significant rises in serum uric acid among normal men faced with job loss.

One difficulty which arises when trying to relate rheumatic complaints to the effort involved in any occupation is that not all workers engaged in the same designated occupation do tasks which involve the same physical effort. Accordingly, the working conditions of each individual in the sample studied by the I.S.U. (Anderson, 1964) were examined and gradings were recorded for each of six variables. Four were concerned with muscular effort, one with posture, and one with climatic conditions. The classification was known by the abbreviation 'BAHLPS' (Back, Arms, Hands, Legs, Posture, and Site). It was similar in application to the PULHEEMS system used for service personnel (Great Britain, 1956) except that the latter describes the man while the BAHLPS assessment describes the job. One grade only is recorded for each of the six factors and the scheme is laid out diagrammatically in Table 6. In general, higher numerical grading indicates greater effort and less comfort and/or warmth.

Seventy-two $(44 \%)$ of the 164 workers with jobs graded I or II (i.e., light) on all four assessments of effort (i.e., back, arms, hands, legs) had rheumatic complaints and $198(43 \%)$ of the 462 graded either IV or V (i.e., heavy) in all four assessments. Studies were made to see if there was any relationship between a high grading and a high prevalence of rheumatic disease. Increasing effort by back, arms or legs significantly increased the likelihood of rheumatic complaints in general and disc disease in particular, but outdoor conditions showed no such trend.

${ }^{1}$ Graham and Scott (1970) did, however, show a social class gradient for gout.

TABLE 6

OUTLINE OF JoB ANALYSIS

\begin{tabular}{c|l|c|c}
\hline Grade & Back, arms, hands, legs & Posture & Site \\
\cline { 2 - 4 } I & No effort required & $\begin{array}{c}\text { Mainly sitting or standing in one } \\
\text { position }\end{array}$ & $\begin{array}{c}\text { Office or heated workshop with } \\
\text { only occasional outdoor work }\end{array}$ \\
\cline { 2 - 4 } & Slight effort & $\begin{array}{c}\text { Some standing and moving } \\
\text { around }\end{array}$ & Indoor workshop-intemperate \\
\hline III & Moderate effort & $\begin{array}{c}\text { Mainly standing including some } \\
\text { moving around }\end{array}$ & $\begin{array}{c}\text { Intemperate workshop with } \\
\text { some outdoors }\end{array}$ \\
\hline IV & $\begin{array}{c}\text { Maximum effort but not sus- } \\
\text { tained for long periods }\end{array}$ & $\begin{array}{c}\text { Standing at all times including } \\
\text { moving around }\end{array}$ & Mainly outdoors \\
\hline V & $\begin{array}{c}\text { Maximum effort sustained for } \\
\text { long periods }\end{array}$ & $\begin{array}{c}\text { Walking long distances (i.e. } 1 \\
\text { mile +) }\end{array}$ & Outdoors all weathers \\
\hline
\end{tabular}


Prevention and management of rheumatic diseases in workers

Many of the studies reviewed so far have shown that some rheumatic diseases are occupationally linked. It seems logical, therefore, to consider how their onset might be prevented or delayed. In an ideal world someone with high serum uric acid might be discouraged from brewing and a patient with tenosynovitis, wanting to work as a typist, might be advised to seek alternative employment while a man with spondylolisthesis may have the onset of back pain delayed if he can be kept away from coal mining. The identification of potentially vulnerable individuals is difficult, however, and the relationship between early changes and the ultimate outcome seldom justifies extensive rejections.

Low back pain as a potential basis for industrial compensation in the United States was stressed by Pillmore (1960) and Becker (1961) while Wilson (1962) estimated that non-skeletal back injuries had cost nearly 25 million dollars in New York State in one year. The use of preplacement examinations and radiology by Kosiak, Aurelius, and Hartfiel (1966; 1968) resulted in the classification of 1181 out of a total of 4103 potential employees as unacceptable as previous litigation had held employers to be negligent for permitting employees with known defects to undertake potentially hazardous activities. Exclusions of this kind may be justified to reduce compensation but unless alternative employment is available this is seldom in the best interests of would-be breadwinners.

Periodic examinations to assist early discovery of serious disease may replace or supplement initial examinations. Magnuson (1969) was unimpressed by their value, a view shared by Rowe (1969) in relation to low back pain. Their role in respect of other rheumatic diseases seems equally problematical as little can be done with someone already in employment who is found to be developing symptoms. It may be impractical (e.g., on grounds of intellectual ability) to transfer him to clerical work while the reduced income often associated with such changes may cause difficulties. Furthermore, as Daniel (1969) pointed out, transference to new occupations may cause problems with union membership. There is much to be said for avoiding change if possible, and rehabilitation is best carried out in what is regarded as the 'normal' environment. Thus Jaffe, Day, and Adams (1964) found that injured men had more chance of returning to productive employment when placed with their own firms, especially if they were returned to their original jobs.

In Britain at the present time rheumatic diseases are not regarded as 'industrial' in the statutory sense. Back pain (especially disc disorders) and osteoarthrosis may be related to heavy occupations but criteria will have to be a lot clearer before the State will accept responsibility for compensating a man with degenerative rheumatic disease merely because he has done heavy manual work.

Even if periodic examinations helped to identify potential sufferers it is possible that such identification might adversely affect some claims for Industrial Injury Benefit for back strain resulting from an injury at work under the existing British National Insurance Acts. In this connexion Edmonds and Kerr (1960) found that $41 \%$ of 73 miners who had changed from coalface work did so because of 'injury' while $34 \%$ changed because of 'illness'.

Another way of trying to reduce the effects of rheumatic disease would be to modify working conditions in terms of such things as climatic conditions or physical effort. There is general agreement that climate has little effect on the incidence of rheumatic diseases and though Anderson and Duthie (1963) found complaint ratios slightly higher among indoor than outdoor workers, this may have resulted from self selection or earlier enforced change by those with established rheumatism. There is insufficient evidence at present therefore to justify wholesale transference of rheumatic sufferers to indoor employment.

Prolonged physical effort does appear to predispose to degenerative disc disease and osteoarthrosis. Troup (1965) indicated his agreement with the British maximum handling loads of $25 \mathrm{~kg}$ (compact load) for young men and $59 \mathrm{~kg}$ for those who were fully developed. However, there are no statutory limits for prolonged handling of lesser weights though Davis and Troup (1964) discussed the effects on the trunk of handling heavy loads in different postures and Anderson (1960) suggested methods of lifting and handling bulky loads.

Modification of the load or a change to lighter work for those with chronic back pain is probably justified whenever practicable but this is not the whole answer. Partridge and Anderson (1969) commented on the relationship between back pain and sedentary occupations. Anderson and his colleagues (1962) also noticed a high incidence of disc diseases among coal miners working away from the coal face. Prolonged standing or walking, though related to a significant increase in back pain as a whole, did not have such a relationship with disc disease (Anderson, 1964). Furthermore, White (1966) subjected patients, disabled with low back pain, randomly to different forms of therapy and concluded that mild exercise did not produce significantly better results than vigorous exercise. Further study of physiological and ergonomic considerations in relation to heavy lifting, as suggested by Troup and his colleagues (1970b) and Anderson and his colleagues (1962), are needed. 
In particular, a prospective study in relation to job changes would be useful.

Apart from early detection and the modification of environment or effort there are other measures which may help those with established disease. The Disabled Persons Register, rehabilitation programmes, and boosting morale are among the more important.

The relatively small proportion of men registered as disabled among those who ascribed job changes to rheumatism has already been noted and Taylor and Fairrie (1968b) have commented on the lack of understanding of the Register by doctors, managers, and the disabled themselves.

Sickness absence rates for those with chronic disc disease or rheumatoid arthritis are fairly high and such men continually risk losing their jobs; unless they are to be written off completely some rehabilitative measures are necessary. In recent years rehabilitation centres for those with chronic physical disabilities have been increased (Ministry of Health, 1963) but unfortunately not all authorities are agreed on the best approach.

Efficient rehabilitation can be achieved only if correct diagnosis and therapy have been established as the long-term prognosis depends on these. Duthie (1968) and Bianco (1968) both stressed this and Duthie also commented on the need for co-operation between industrial medical officers and personal physicians. In this connexion a useful contribution has been made by industries themselves establishing rehabilitation workshops; Stewart (1954) and Plewes, Barron, Thompson, and Newell (1948) have described such units where absences from fractures and disc disease have been reduced dramatically. In addition both papers stressed the importance of job description and the value of having an industrial medical officer in the supervising team. Taylor and Fairrie (1968a) looked at the disabilities of 366 men and found 21 out of 66 with back complaints and 7 out of 13 with polyarthritis who were either totally unfit or who had already changed or modified their work. This sort of study indicates the size of the problem facing large industrial firms trying to rehabilitate their own staff.

Rehabilitation in hospital tends to be based on such principles as muscle-strengthening exercises complemented by appropriate occupational activities. Baths still play an important part and Cosh and Kersley (1969) have described interesting developments at Bath, one of the original spas in Britain. Much of the literature is concerned with the relatively small numbers disabled by rheumatoid arthritis rather than the numerically larger group with back pain. This may be because effective recovery follows many such episodes; the proportion varies with site and severity but a claim of $85 \%$ has been made by Gordon (1968). Furthermore, opinion is divided as to whether physical activity programmes of the kind advocated by Duggar and Swengros (1969) are of as much value as Kraus and Raab (1961) have claimed. Nachemson and Lindh (1969), observing older male patients with low back pain as well as controls, found little difference in abdominal muscle strength between the two groups unless the incapacity was of long duration. With younger men, however, there was a difference and this could affect the protection afforded to the spine.

Burry and Graham (1970) are currently recording success in treating men suffering from nerve root irritation of the lumbosacral region at the Hume Kendall rehabilitation unit of the Guy's group of hospitals. The criteria adopted are similar to those of the I.S.U. for disc degeneration; all but one out of 40 men have returned to their original employment. Patients are selected on the basis that they will probably be suitable for treatment by bed rest and local injection complemented by hydrotherapy and active exercises. Such selection means others are passed over and hospital specialists have difficulty in assessing the proportion of potential patients in the population as a whole. Some attempt should also be made at cost benefit analysis for patients receiving hospital treatment along the lines adopted by Brooks (1969) for those attending the Glasgow Centre.

Liaison between doctors and Disablement Resettlement Officers is not always good. This lack of rapport is not confined to hospital, and Anderson and Warren $(1966 ; 1967)$ showed that general practitioners were not always aware of available services. One experiment, in which the Department of Employment and Productivity has been linked with a hospital rehabilitation unit at Garston Manor (Mattingly, 1968), appears to have been successful with some difficult cases but the whole question of rehabilitation in relation to health services requires reconsideration. Duthie (1970) discussed rehabilitation with particular reference to its inclusion as part of the specialty of rheumatology. He indicated that rheumatology was a sufficiently complex subject in its own right and suggested that specialists in that field should not have their training diluted by having to make a comprehensive study of rehabilitative methods. He suggested rather that special consultants should be appointed with responsibility for the whole field of rehabilitation. This would imply that their interests would not be confined to rehabilitating those with locomotor disorders. A sound knowledge of all conditions leading to disability and the limitations of known therapy was needed together with knowledge of available services outside hospital by a fully integrated member of the hospital staff.

Notkin (1951) listed psychometry, counselling, training, and placement as essential features in a 
rehabilitation programme. Daniel (1969) stressed the importance of being familiar with effort requirements when placing men in suitable jobs. Possibly a classification such as the BAHLPS system might be helpful in this field. Another important aspect is that of raising morale in men having difficulty in remaining employed.

Governmental attitudes are also important. Hosey and Lerice-Ede (1968) stressed the need to review the occupational health laws in the United States of America in the light of the Presidential Statement on occupational health. In Britain, however, the Department of Health and Social Security (1970) has not suggested that occupational health services should become part of an integrated health service and further fragmentation of rehabilitative services may result from the plans (Great Britain, 1968) to separate many social services for the handicapped from the medical services by putting the former under the control of local authorities. The establishment of these interfaces will increase the communication difficulties between doctors, social workers, and others concerned in helping rheumatic patients back to work.

\section{Conclusion}

This review of rheumatism in industry has indicated that the growing interest in this field is a comparatively recent development and that much research still requires to be done to establish more clearly the nature and cause of many musculoskeletal pains especially in the back.

The degenerative diseases and back pains are numerically the most important rheumatic causes of absence and permanent disability and their effects are formidable in terms of loss of earnings; those affected also make heavy demands on medical services. However, the extent to which occupational hazards cause permanent changes in the musculoskeletal system is difficult to assess. More studies should be made on those who have retired prematurely, changed jobs or been off work for long periods, while a prospective study of working capacity over a long period would shed more light on factors about the man, his rheumatic disease, and his job which affect the prognosis.

Primary prevention of the rheumatic diseases seems to be out of reach at the present time and treatment is successful only in selected cases. There remains a large number of patients requiring rehabilitation and this problem is likely to increase rather than decrease. Serious consideration should be given to the idea that closer liaison could be established between the health services and industry by the appointment of specialists in rehabilitation by area health authorities or whatever bodies are to run the health services of tomorrow. These specialists, who should have special training and equal status with other consultants, would be the principal medical members of the rehabilitating team not only for rheumatic diseases but for all disabling conditions.

One of the main difficulties in planning and conducting research on rheumatic diseases is the lack of diagnostic clarity. The different views and interests of rheumatologists, neurologists, and orthopaedic surgeons mean that nomenclature may vary widely. One way of helping to resolve these differences would be for those engaged in the practice of occupational medicine both in the field and in academic departments to conduct joint research with the physicians and surgeons treating these conditions in hospitals and domiciliary practice.

The work which formed the basis for part of this paper was done while the author was employed as Medical Officer in charge of the Industrial Survey Unit financed by the Arthritis and Rheumatism Council. Acknowledgement is made to the other members of the Unit and in particular to Professor J. J. R. Duthie for his helpful comments.

Miss R. Dalton and Mr. M. Curwen of Guy's Hospital Medical School kindly helped with the statistical material.

\section{References}

Abel Smith, B. (1968). Proceedings of seminar on health economics. W.H.O. (Moscow).

Abrams, N. R. (1960). Etiology and pathogenesis of osteoarthritis. In Arthritis, edited by J. L. Hollander, 6th ed., pp. 811-829, Kimpton, London.

Acheson, R. M. (1969). Social class gradients and serum uric acid in males and females. Brit. med.J., 4, 65-67.

Adams, F. (1886). Translation: The Genuine Works of Hippocrates. Wood, New York.

Anderson, J. A. D. (1964)., Rheumatism in industry. M.D. thesis (Edinburgh).

- and Duthie, J. J. R: (1963). Rheumatic complaints in dockyard workers. Ann. rheum. Dis., 22, 401-409.

,-- and Moody, B. P. (1962). Social and economic effects of rheumatic diseases in a mining population. Ann. rheum. Dis., 21, 342-352.

,-- , and - (1963). Rheumatic diseases affecting men registered as disabled. Ann. rheum. Dis., 22, 188-193. and Warren, E. A. (1966). Communications with general practitioners. Some methods of disseminating information about health and welfare services. Med. Offr, 116, 333-337.

and - (1967). Communications with general practitioners II. Med. Offr, 118, 45-51.

Anderson, T. McL. (1960). Manual of Lifting and Handling. Industrial Welfare Society, London.

Ansell, B. M. (1969). Rheumatology in general practice: social problems. J. roy. Coll. gen. Practit., 18, Suppl. 3, 21-24.

Arnott, A. W., and Grieve, D. W. (1969). The relationship between torque and velocity of axial rotation of the human trunk during maximum effort. J. Physiol. (Lond.), 201, 87P-88P.

Arthritis and Rheumatism Council (1964). Annual report. London.

Arthritis and Rheumatism Council Field Unit (1969). Digest 
of morbidity and mortality data on the rheumatic diseases Ann. rheum. Dis., 28, 443-446.

Arthritis and Rheumatism Council Industrial Survey Unit (1969). Rheumatism in Industry. London.

Baillou, G. de (1762). Liber de rhumatismo. Geneva.

Barber, H. S. (1957). Myalgic syndrome with constitutional effects. Ann. rheum. Dis., 16, 230-237.

Beall, G., and Cobb, S. (1961). The frequency distribution of episodes of rheumatoid arthritis as shown by periodic examination. J. chron. Dis., 14, 291-310.

Beattie, J. W. (1953). Dyspeptic backache. Ann. rheum. Dis., 12, 223-226.

Becker, W. F. (1961). Prevention of low back disability. J. occup. Med., 3, 329-335.

Bell, A. (1969). Guest editorial: Challenges. Industr. Med. Surg., 38, no. 5 (May), pp. 28-30.

Bennett P. H., and Wood, P. H. N., Ed. (1968). Population Studies of the Rheumatic Diseases. Proc. 3rd int. Symp., New York, 1966; (Exc. med. int. Congr. Ser. no. 148). Arthritis and Rheumatic Foundation, New York.

Bianco, A. J. (1968). Low-back pain and sciatica; diagnosis and indications for treatment. J. Bone Jt Surg., 50A. 170-181.

de Blécourt. J. J. (1954). 'Screening' of the population for rheumatic diseases. Ann. rheum. Dis., 13, 338-340.

- Boerma, F. W., Nienhuis, R. L. F., Mandema, E., and Jansz, A. (1963). Population studies of rheumatic diseases on a coastal island. Ann. rheum. Dis., 22, 429-434.

Blumberg, B. S., Bunim, J. J., Calkins, E., Pirani, C. L., and Zvaifler, N. J. (1964). ARA nomenclature and classification of arthritis and rheumatism (tentative). Arthr. and Rheum., 7, 93-97.

Boasson, M., Forestier, J., Certonciny, A., Forestier, F., and Auquier, L. (1969). Durée des manifestations douloureuses dans les arthroses vertébrales. Rev. Rhum., 36, 151-160.

Bole, G. G., Friedlaender, M. H., and Smith, C. K. (1969). Rheumatic symptoms and serological abnormalities induced by oral contraceptives. Lancet, 1, 323-326.

Bollet, A. J. (1969). An essay on the biology of osteoarthritis. Arthr. and Rheum., 12, 152-163.

Boule, M. (1923). Fossil Men, Ch. IV, p. 103, translated by J. E. Ritchie and J. Ritchie. Oliver and Boyd, Edinburgh.

Bradshaw, P. (1957). Some aspects of cervical spondylosis. Quart. J. Med., 26, 177-208.

Bremner, J. M. (1961). Rheumatic complaints in a rural population. Ann. rheum. Dis., 20, 149-160.

, Lawrence, J. S., and Miall, W. E. (1968). Degenerative joint disease in a Jamaican rural population. Ann. rheum. Dis., 27, 326-332.

British Medical Association (1953). Report of the second plenary session of annual meeting. Brit. med.J., 2, 205.

Brooks, R. G. (1969). Cost-benefit analysis of patients treated at a rheumatism centre. Ann. rheum. Dis., 28, 655-661.

Brown, R., and Lingg, C. (1961). Musculoskeletal complaints in an industry. Annual complaint rate and diagnosis, absenteeism and economic loss. Arthr. and Rheum., 4, 283-302.

Bull, J., El Gammal, T., and Popham, M. (1969). A possible genetic factor in cervical spondylosis. Brit. J. Radiol., 42, 9-16.

Burry, H. C., and Graham, R. (1970). Personal communication.

Caplan, P. S., Freedman, L. M. J., and Connelly T. P. (1962). Degenerative joint disease of the lumbar spine in coal miners-a clinical and $x$-ray study. Arthr. and Rheum., 5, 288.

Christian, C. L., Ed. (1968). Eighteenth rheumatism review. Arthr. and Rheum., 11, Suppl., 523-718.

Claussen, F. (1955). Beiträge der Zwillings-Forschung zum Rheuma-Problem. $Z$. Rheumaforsch., 14, 145-152.
Cobb, S. (1965). The epidemiology of rheumatoid arthritis. Arthr. and Rheum., 8, 76-79.

- Anderson, F., and Bauer, W. (1953). Length of life and cause of death in rheumatoid arthritis. New Engl.J. Med., 249, 553-556.

- and Lawrence, J. (1957). Towards a geography of rheumatoid arthritis. Bull. rheum. Dis., 7, 133-134.

- Merchant, W. R., and Rubin, T. (1957). The relation of symptoms to osteoarthritis. J. chron. Dis., 5, 197-204.

-, Miller, M., and Wieland, M. (1959). On the relationship between divorce and rheumatoid arthritis. Arthr. and Rheum. 2, 414-418.

, Schull, W. J., Harburg, E., Kasl, S. V., and others (1969). The intrafamilial transmission of rheumatoid arthritis I-VIII. J. chron. Dis., 22, 193-296.

, Thompson, D. J., Rosenbaum, J., Warren, J. E., and Merchant, W. R. (1956). On the measurement of prevalence of arthritis and rheumatism from interview data. J. chron. Dis., 3, 134-139.

Collette, J., and Ludwig, E. G. (1968). Low back disorders: an examination of a stereotype. Industr. Med. Surg., 37 685-687.

Cosh, J. A., and Kersley, G. D. (1969). Rheumatism treatment centres in Britain-Bath ancient and modern. Ann. phys. Med., 10, 167-174.

Dahlberg, G., and Grubb, I. (1951). Chronic rheumatic arthritis and housing conditions. Acta genet. (Basel), 2, 42-56.

Daniel, J. W. (1969). Rehabilitation and resettlement of patients suffering from rheumatical disorders. J. roy. Coll. gen. Practit., 18, Suppl. 3, 29-32.

Davis, P. R. (1959). Posture of the trunk during the lifting of weights. Brit. med. J., 1, 87-89.

- and Troup, J. D. G. (1964). Pressures in the trunk cavities when pulling, pushing and lifting. Ergonomics, 7, 465-474.

Department of Health and Social Security (1970). The Future Structure of the National Health Service, H.M.S.O., London.

Department of Health for Scotland (1945). Chronic rheumatic diseases; report of the Medical Advisory Committee (Scotland). H.M.S.O., Edinburgh.

Dillane, J. B., Fry, J., and Kalton, G. (1966). Acute back syndrome. Brit. med. J., 2, 82-84.

Diveley, R. L., Kiene, R. H., and Meyer, P. W. (1956). Low back pain. J. Amer. med. Ass., 160, 729-731.

- and Oglevie, R. R. (1956). Preemployment examinations of the low back. J. Amer. med. Ass., 160, 856-858.

Duggar, B. C., and Swengros, G. V. (1969). The design of activity programs for industry. J. occup. Med., 11, 322-329.

Duthie, J. J. R. (1962). Personal communication.

- (1970). Rheumatology as a speciality in medicine: a personal appraisal. Scot. med. J., 15, 165-168. and Alexander, W. R. M., Ed. (1968). Rheumatic Diseases. Edinburgh University Press.

- and Anderson, J. A. D. (1962). Social and economic effects of rheumatic disease. Arch. environm. Hlth, 4, 511-518.

-, Brown, P. E., Truelove, L. H., Baragar, F. D., and Lawrie, A. J. (1964). Course and prognosis in rheumatoid arthritis. Ann. rheum. Dis., 23, 193-204.

- Stewart, S. M., Alexander, W. R. M., and Dayhoff, R. E. (1967). Isolation of diphtheroid organisms from rheumatoid synovial membrane and fluid. Lancet, 1, 142-143.

- Thompson, M., Weir, M. M., and Fletcher, W. B. (1955). Medical and social aspects of the treatment of rheumatoid arthritis. Ann. rheum. Dis., 14, 133-149.

Duthie, R. B. (1968). The rheumatic diseases and employment. Trans. Soc. occup. Med., 18, 67-70. 
Ecker, A. (1843). Ueber Abnützung und Zerstörung der Gelenkknorpel. Arch. physiol. Heilk., 2, 235-248.

Edmonds, O. P., and Kerr, D. S. (1960). Occupational life history of the coal-face worker at two collieries. Brit. $J$. industr. Med., 17, 234-237.

Ellis, M. (1961). The relief of pain by cooling of the skin. Brit. med. J., 1, 250-252.

Ellman, P. and Shaw, D. (1950). The "chronic rheumatic" and his pains; psychosomatic aspects of chronic nonarticular rheumatism. Ann. rheum. Dis., 9, 341-357.

Erkrath, F. A., and Strauch, W. (1968). Kreuzschmerzen und Leistungsminderung bei weiblichen Beschäftigen. Dtsch. Gesundh.-Wes., 23, 1125-1129.

Falconnet, M., and Vignon, G. (1968). Étude statistique étiologique et clinique de 200 observations de coxarthrose. Lyon méd., 219, 1171-1186.

Frenkil, J. (1959). Some considerations in the employment of arthritics in industry. Arch. industr. Hlth, 20, 359-364.

Froggatt, P. (1970). Short-term absence from industry I, II, and III. Brit. J. industr. Med., 27, 199-210, 211-224, 297-312.

General Register Office and General Register Office (Scotland) (1953). Decennial Supplement National Census-Occupation. H.M.S.O., London.

Gill, D. (1968). Rheumatic complaints of women using antiovulatory drugs: an evaluation. J. chron. Dis., 21, 435-444.

Glover, J. R. (1960). Back pain and hyperaesthesia. Lancet, 1, $1165-1169$.

Gordon, E. J. (1968). Diagnosis and treatment of acute low back disorders. Industr. Med. Surg., 37, 756-761.

Gordon, I. (1960). Polymyalgia rheumatica. Quart.J. Med., 29, 473-488.

Graham, R., and Scott, J. T. (1970). Clinical survey of 354 patients with gout. Ann. rheum. Dis., 29, 461-468.

Great Britain (1956). A system of classification for service personnel. London.

- (1968). Report of the Committee on Local Authority and Allied Personal Social Services. Cmnd. 3703, H.M.S.O., London.

Hart, F. D. (1969). Polymyalgia rheumatica. Brit. med. J., 2, 99-100.

Haygarth, J. (1813). A Clinical History of Disease. Vol. 1: Acute Rheumatism. Vol. 2: Nodosity of Joint. London.

Heald, C. B. (1952). Fibrositis in industry and the LaughtonScott technique. Trans. Ass. industr. med. Offrs, 2, 106-109.

Heberden, W. (1803). Commentaries on the History and Cure of Disease, 2nd ed. Chapter 28 Digitorum Nodi. Payne, London.

Hench, P. S., Ed. (1948). Rheumatism and arthritis: review of American and English literature of recent years (Ninth rheumatism review). Ann. intern. Med., 28, 66-168.

Hill, A. G. S. (1968). The role of infection in the causation of rheumatoid arthritis. Proc. roy. Soc. Med., 61, 971-972.

Hirsch, A. (1886). Handbook of Geographical and Historical Pathology, Vol. III, Chapter XVII, pp. 511-512. (Translated from Second German Edition by Creighton, C.) The New Sydenham Society. London.

Hirsch, C. (1966). Etiology and pathogenesis of low back pain. Israel J. med. Sci., 2, 362-370.

, Ingelmark, B. E., and Miller, M. (1963). The anatomical basis for low back pain. Acta. orthop. scand., 33, 1-17.

Hollander, J. L. (1966). Introduction to arthritis and the rheumatic diseases. In Arthritis and Allied Conditions. Edited by J. L. Hollander, 7th ed., pp. 23-33, Kimpton, London.

Horal, J. (1969). The clinical appearance of low back disorders in Gothenburg, Sweden. Acta orthop. scand., Suppl. 118.

Hosey, A. D., and Lerice-Ede, J. D. (1968). Occupational health legislation: the need for review. Amer. industr. Hyg. Ass. J., 29, 495-498.

Jaffe, A. J., Day, L., and Adams, W. (1964). Disabled Workers in the Labour Market, p. 73, Bedminster Press.

Jefferys, M., Millard, J. B., Hyman, M., and Warren, M. D. (1969). A set of tests for measuring motor impairment in prevalence studies. J. chron. Dis., 22, 303-319.

Kalbak, K. (1953). Rheumatic diseases in Denmark. Ann. rheum. Dis., 12, 306-309.

Kahlmeter, G. (1923). Examen statistique des causes d'invalidité fait d'après les demandes addressées à La 'Direction des Pensions de Retraite' pendant l'année 1918 , sur lesquelles les pensions supplémentaires furent accordées. Acta med. scand., 59, 153-179.

- (1936). The prevention of permanent disability and the measures to be taken in the case of invalids, especially those suffering from the sequelae of rheumatism. Quart. Bull. Hlth Org. L.o.N., 5, 269-276.

Kasl, S. V., Cobb, S., and Brooks, G. W. (1968). Changes in serum uric acid and cholesterol levels in men undergoing job loss. J. Amer. med. Ass., 206, 1500-1507.

Keefer, C. S., Parker, F., Myers, W. K., and Irwin, R. L. (1934). Relationship between anatomic changes in knee joint with advancing age and degenerative arthritis. Arch. intern. Med., 53, 325-344.

Kellgren, J. H. (1964). The epidemiology of rheumatic diseases. Ann. rheum. Dis., 23, 109-122.

(1966). Epidemiology of rheumatoid arthritis. Arthr. and Rheum., 9, 658-674.

and Lawrence, J. S. (1952). Rheumatism in miners. Part II: X-ray study. Brit. J. industr. Med., 9, 197-207. and - (1956). Rheumatoid arthritis in a population sample. Ann. rheum. Dis., 15, 1-11.

and - (1958). Osteo-arthrosis and disk degeneration in an urban population. Ann. rheum. Dis., 17, 388-397.

- - and Aitken-Swan, J. (1953). Rheumatic complaints in an urban population. Ann. rheum. Dis., 12, 5-15.

,-- , and Bier, F. (1963). Genetic factors in generalized osteo-arthrosis. Ann. rheum. Dis., 22, 237-255.

and Moore. R. (1952). Generalized osteoarthritis and Heberden's nodes. Brit. med. J., 1, 181-187.

Kidd, C. W., and Park, A. T. (1960). Arthritis and rheumatism in the insured population of Northern Ireland. Ann. rheum. Dis., 19, 158-162.

King, S. H. and Cobb, S. (1958). Psychosocial factors in the epidemiology of rheumatoid arthritis. J. chron. Dis., 7, 466-475.

Kosiak, M., Aurelius, J. R., and Hartfiel, W. F. (1966). Backache in industry. J. occup. Med., 8, 51-58.

,-- , and - (1968). The low back problem. J. occup. Med., 10, 588-593.

Kraft, G. H., Johnson, E. W., and LaBan, M. M. (1968). The fibrositis syndrome. Arch. phys. Med., 49, 155-162.

Kraus, H., and Raab, W. (1961). Hypokinetic disease, Charles C. Thomas, Springfield, Illinois.

Lawrence, J. S. (1955). Rheumatism in coal miners. Part III. Occupational factors. Brit. J. industr. Med., 12, 249-261. (1961a). Prevalence of rheumatoid arthritis. Ann. rheum. Dis., 20, 11-17.

(1961b). Rheumatism in cotton operatives. Brit. J. industr. Med., 18, 270-276.

(1969a). Disc degeneration. Its frequency and relationship to symptoms. Ann. rheum. Dis., 28, 121-138.

- (1969b). Generalized osteoarthrosis in a population sample. Amer. J. Epidem., 90, 381-389.

- and Aitken-Swan, J. (1952). Rheumatism in miners. Part I. Rheumatic complaints. Brit. J. industr. Med., 9, $1-18$.

- and Bennett, P. H. (1960). Benign polyarthritis. Ann. rheum. Dis., 19, 20-30. 
-, Bremner, J. M., and Bier, F. (1966). Osteo-arthrosis: prevalence in the population and relationship between symptoms and X-ray changes. Ann. rheum. Dis., 25, 1-24.

Lawrie, A. J. (1960). The role of the medical social worker in the care of patients with rheumatoid arthritis. Almoner, 13, 128-140.

Lewis-Faning, E. (1950). Report of an enquiry into the aetiological factors associated with rheumatoid arthritis. Ann. rheum. Dis., 9, Suppl. 1-94.

Lindén, V. (1969). Absence from work and physical fitness. Brit. J. industr. Med., 26, 47-53.

Lockshin, M. D., Higgins, I. T. T., Higgins, M. W., Dodge, H. J., and Canale, N. (1969). Rheumatism in mining communities in Marion County, West Virginia. Amer.J. Epidem., 90, 17-29.

Logan, W. P. D. (1960). Morbidity Statistics from General Practice. General Register Office Studies on Medical and Population Subjects. No. 14, Vol. 2 (Occupation). H.M.S.O., London.

- and Cushion, A. A. (1958). Morbiditv Statistics from General Practice. General Register Office Studies on Medical and Population Subjects No. 14, Vol. 1 (General). H.M.S.O., London.

Lowman, E. W., Miller, S., Lee, P. R., Stein, H., King. R. and Heald, L. (1954). Psycho-social factors in rehabilitation of the chronic rheumatoid arthritic. Ann. rheum. Dis., 13, 312-316.

McCallum, R. I., Stanger, J. K., Walder, D. N., and Paton, W. D. M. (1954). Avascular necrosis of the femoral heads in a compressed air worker. J. Bone Jt Surg., 36B, 606-611.

McGregor, D. (1960). Sickness absence among forestry workers in the North of Scotland, 1958. Brit. J. industr. Med., 17, 310-317.

Magnuson, H. J. (1969). A periodic examination program for occupational health. J. occup. Med., 11, 349-354.

Matthews, J. (1964a). Ride comfort for tractor operators I. Review of existing information. J. agric. engng. Res., 9, 3-31.

(1964b). Ride comfort for tractor operators II. Analysis of ride vibrations on pneumatic-tyred tractors. J. agric. Engng. Res., 9, 147-158.

Mattingly, S. (1968). Garston Manor: an experiment in rehabilitation. Brit. med.J., 3, 46-49.

Meyerowitz, S., Jacox, R. F., and Hess, D. W. (1968) Monozygotic twins discordant for rheumatoid arthritis. Arthr. and Rheum., 11, 1-21.

Miall, W. E. (1955). Rheumatoid arthritis in males. Ann. rheum. Dis., 14, 150-158.

— Ball, J., and Kellgren, J. H. (1958). Prevalence of rheumatoid arthritis in urban and rural populations in South Wales. Ann. rheum. Dis., 17, 263-272.

Mikkelsen, W. M., and Dodge, H. (1969). A four year followup of suspected rheumatoid arthritis. Arthr. and Rheum., 12, 87-91.

Ministry of Health (1924). The Incidence of Rheumatic Diseases. Reports on public Health and Medical Subjects, No. 23, H.M.S.O., London.

(1963). On the State of the Public Health: the Annual Report of the Chief Medical Officer for 1962. H.M.S.O., London.

Ministry of Pensions and National Insurance (1956). Digest of Statistics analysing Certificates of Incapacity 1955/56, London.

Moore, S. R. W. (1969). The mortality and morbidity of deep sea fishermen sailing from Grimsby in one year. Brit. $J$. industr. Med., 26, 25-46.

Moos, R. H. (1964). Personality factors associated with rheumatoid arthritis: a review. J. chron. Dis., 17, 41-55.

Movin, A. (1967). Myelographic appearances of disk protrusions in different positions. Acta radiol. Diagn., 6, 524-528.
Mueller, A. D., Lefkovits, A. M., Bryant, J. E., and Marshall, M. L. (1960). Some psychosocial factors in patients with rheumatoid arthritis. Arthr. and Rheum., 3, 456-457.

,,--- , and - (1961). Some psychosocial factors in patients with rheumatoid arthritis. Arthr. and Rheum., 4, 275-282.

Nachemson, A., and Lindh, M. (1969). Measurement of abdominal and back muscle strength with and without low back pain. Scand. J. rehab. Med., 1, 60-65.

Nelson, S. G., and Lancaster, H. O. (1959). A morbidity survey of rheumatism in Sydney. Med. J. Aust., 1, 190-193.

Notkin, H. (1951). Vocational rehabilitation and public health. Amer. J. publ. Hlth, 41, 1096-1100.

Oakes, T. W., Ward, J. R., Gray, R. M., Klauber, M. R., and Moody, P. M. (1970). Family expectations and arthritis patient compliance to a hand resting splint regime. $J$. chron. Dis., 22, 757-764.

Parsons, T. (1951). The Social System. Free Press, Glencoe, Illinois.

Partridge, R. E. H., and Anderson, J. A. D. (1969). Backpain in industrial workers: abstract 284. Proc. XII int. rheum. Congr., Prague.

_ and Duthie, J. J. R. (1964). Le rhumatisme chez les ouvriers de l'industrie. Méd. et Hyg. (Genève), 22, 360-362.

McCarthy, M. A., and Duthie, J. J. R. (1965) Rheumatism in light industry. Ann. rheum. Dis., 24, 332-340.

,-- , and $-(1968)$. Rheumatic complaints among workers in iron foundries. Ann. rheum. Dis., 27, 441-453.

—_ and Duthie, J. J. R. (1968). Rheumatism in dockers and civil servants. Ann. rheum. Dis., 27, 559-568.

- and Knox, J. D. E. (1969). Rheumatic complaints in general practice. J. roy. Coll. gen. Practit., 17, 144-154.

Pillmore, G. U. (1960). The occupational low back hazard. Industr. Med. Surg., 29, 28-32.

Plewes, L. W., Barron, J. N., Thompson, A. R., and Newell, H. H. (1948). Rehabilitation in industry. Lancet, 2 , 699-702.

Pommer, G. (1927). Über die mikroskopischen Kennzeichen und die Entstehungsbedingungen der Arthritis deformans Virchows Arch. path. Anat., 263, 434-514.

Ray, M. B. (1932). The prevention and treatment of industrial rheumatism. J. State Med., 40, 255-273.

Richardson, I. M. (1956). A socio-medical study of 200 unemployed men. Med. Offr, 96, 165-170.

Ropes, M. W., Bennett, G. A., Cobb, S., Jacox, R., and Jessar, R. A. (1956). Proposed diagnostic criteria for rheumatoid arthritis. Bull. rheum. Dis., 7, 121-124.

Rose, B. S., and Prior, I. A. M. (1963). A survey of rheumatism in a rural New Zealand Maori community. Ann. rheum. Dis., 22, 410-415.

Rowe, M. L. (1969). Low back pain in industry. J. occup. Med., 11, 161-169.

Ruffer, M. A. (1921). Studies in the paleopathology of Egypt, ed. R. L. Moodie. University of Chicago Press.

Ruhl, M. J., and Sokoloff, U. (1965). A thesaurus of rheumatology. Arth. and Rheum., 8, 95-182.

Saville, P. D., and Dickson, J. (1968). Age and weight in osteoarthritis of the hip. Arthr. and Rheum., 11, 635-644.

Scotch, N. A., and Geiger, H. J. (1962). The epidemiology of rheumatoid arthritis. A review with special attention to social factors. J. chron. Dis., 15, 1037-1067.

Scott, J. T. (1969). Management of gout. Brit. med. J., 3, 456-457.

Scott, R. (1960). Personal communication.

Scudamore, C. (1823). A Treatise on the Nature and Cure of Gout and Gravel, 4th ed. Longman, Hurst, Rees, Orme, and Brown, London. 
Smyth, C. J. (1957). Hereditary factors in gout: a review of recent literature. Metabolism, 6, 218-229.

— Ed. (1960). Rheumatism and arthritis: review of American and English literature of recent years. (Thirteenth rheumatism review). Ann. intern. Med., 53, Suppl.

- (1966). Diagnosis and treatment of gout. In Arthritis and Allied Conditions, Edited by J. L. Hollander, 7th ed., pp. 932-946, Kimpton, London.

Sokoloff, L. (1966). The pathology and pathogenesis of osteoarthritis. In Arthritis and Allied Conditions, Edited by J. L. Hollander, 7th ed., pp. 849-869; Kimpton, London.

Spiera, H., and Plotz, C. M. (1969). Rheumatic symptoms and oral contraceptives. Lancet, 1, 571-572.

Stecher, R. M. (1940). Heberden's nodes: the incidence of hypertrophic arthritis of the fingers. New Engl.J. Med., 222, 300-308.

- (1955). Heberden's nodes. A clinical description of osteo-arthritis of the finger joints. Ann. rheum. Dis., 14, 1-10.

Steinbrocker, O., Spitzer, N., and Friedman, H. H. (1948). The shoulder-hand syndrome in reflex dystrophy of the upper extremity. Ann. intern. Med., 29, 22-52.

Stern, B. J. (1946). Medicine in Industry, Commonwealth Fund, New York.

Stewart, D. (1954). Industrial rehabilitation. In Industrial Medicine and Hygiene, edited by E. R. A. Merewether. Vol. I, chapter 12, pp. 280-320: Butterworth, London.

Stocks, P. (1949). Sickness in the Population of England and Wales in 1944-47. General Register Office Studies on Medicaland Population Subjects. No. 2. H.M.S.O.,London.

Taylor, P. J. (1967a). Shift and day work: a comparison of sickness absence, lateness and other absence behaviour in an oil refinery from 1962 to 1965 . Brit.J. industr. Med., 24, 93-102. (1967b). Individual variations in sickness absence. Brit. J. industr. Med., 24, 169-177.

(1968). Personal factors associated with sickness absence. Brit. J. industr. Med., 25, 106-118.

- and Fairrie, A. J. (1968a). Chronic disabilities and capacity for work. Brit. J. prev. soc. Med., 22, 86-93.

- and - (1968b). Chronic disability in men of middle age. Brit. J. prev. soc. Med., 22, 183-192.

Tichy, H., and Seidel, K. (1969). Beitraege zur Rheumatologie, Vol. 14. Volk und Gesundheit, Berlin.

Tish, A. (1957). Prevalence of disabilities among government employees. A second eight-year analysis. Arch. industr. Hlth, 15, 160-166.

Troup, J. D. G. (1965). Relation of lumbar spine disorders to heavy manual work and lifting. Lancet, 1, 857-861.

- Roantree, W. B., and Archibald, R. (1970a). Industry and the low-back problem. New Scientist, 45, 65-67.

,-- , and $-(1970 \mathrm{~b})$. Survey of causes of lumbar spinal disability; a methodological study. (Private circulation.)

Vaceva, M. (1966). Personal communication.

War Office (1959). The soldier's back; Army Directorate Bulletin (second series) No. 10. W.O. code 12389 (London).

Wells, R. L. (1969). The hard life of people who must work for a living. J. occup. Med., 11, 439-442.

White, A. W. M. (1966). Low back pain in men receiving workmen's compensation. Canad. med. Ass. J., 95, 50-56.

Wilson, P. D. (1962). Low back pain, a problem for industry. Arch. environm. Hlth, 4, 505-510.

World Health Organization (1967-69). Manual of the International Statistical Classification of Diseases, Injuries, and Causes of Death, Based on the Recommendations of the Eighth Revision Conference, 1965. 2 vols. Geneva.

Received for publication July 1, 1970. 